\title{
ॠUSGS
}

science for a changing world

In Cooperation with the Bureau of Land Management

\section{Completion Reports, Core Logs, and Hydrogeologic Data from Wells and Piezometers in Prospect Gulch, San Juan County, Colorado}

By Raymond H. Johnson and Douglas B. Yager
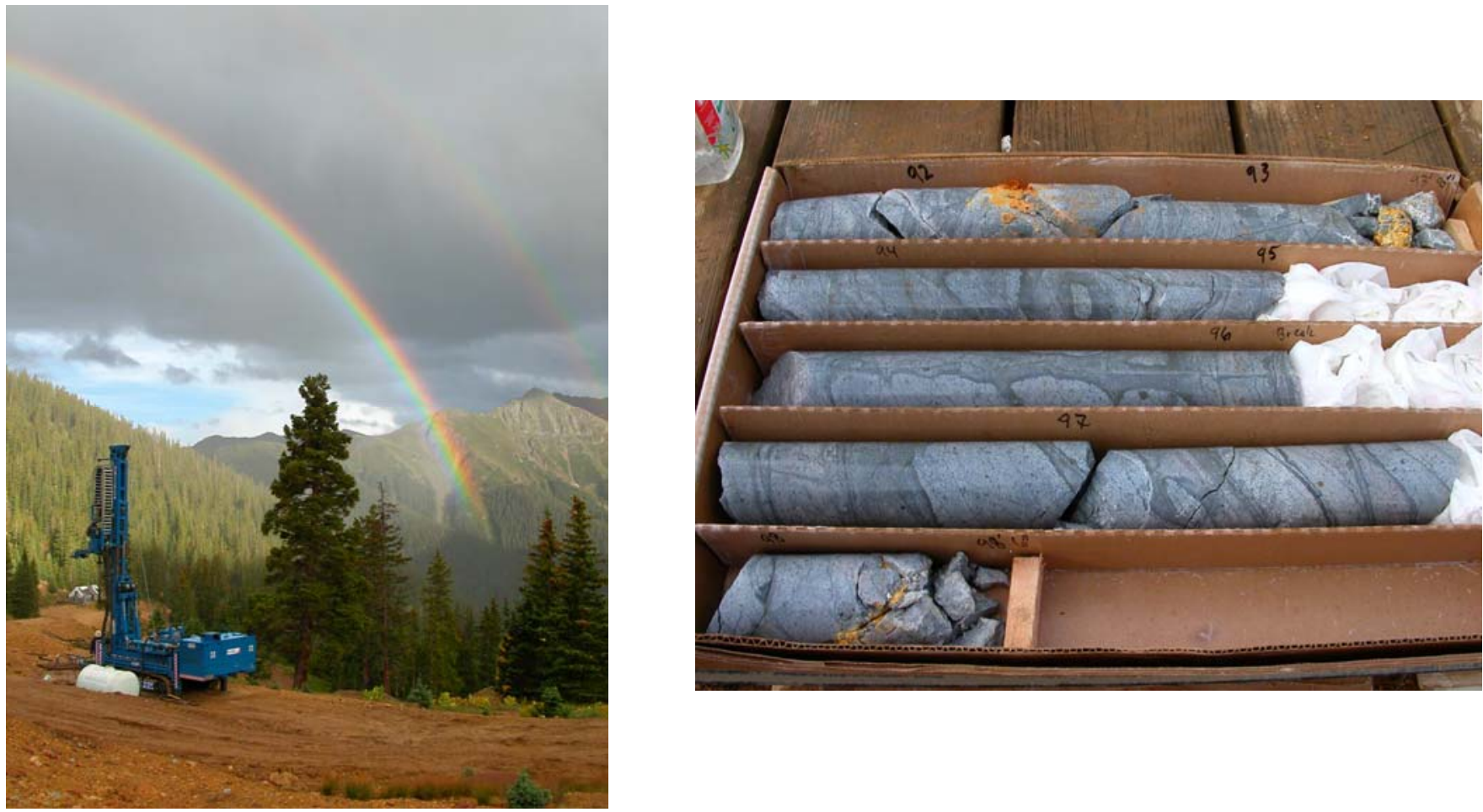

Open-File Report 2006-1030 


\section{U.S. Department of the Interior \\ Gale A. Norton, Secretary}

\section{U.S. Geological Survey \\ P. Patrick Leahy, Acting Director}

U.S. Geological Survey, Reston, Virginia 2006

For product and ordering information:

World Wide Web: http://www.usgs.gov/pubprod

Telephone: 1-888-ASK-USGS

For more information on the USGS - the Federal source for science about the Earth, its natural and living resources, natural hazards, and the environment:

World Wide Web: http://www.usgs.gov

Telephone: 1-888-ASK-USGS

Suggested citation:

Johnson, R.H., Yager, D.B., 2006, Completion reports, core logs, and hydrogeologic data from wells and piezometers in Prospect Gulch, San Juan County, Colorado: U.S. Geological Survey Open-File Report 20061030.

Any use of trade, product, or firm names is for descriptive purposes only and does not imply endorsement by the U.S. Government.

Although this report is in the public domain, permission must be secured from the individual copyright owners to reproduce any copyrighted material contained within this report. 


\section{Contents}

Abstract

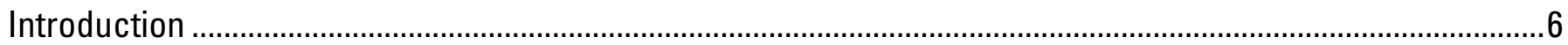

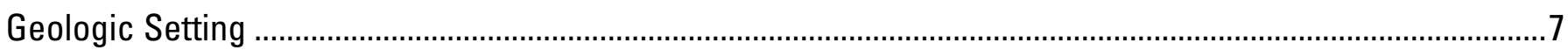

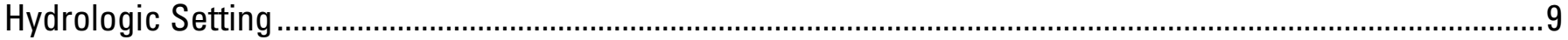

Well and Piezometer Completion Data

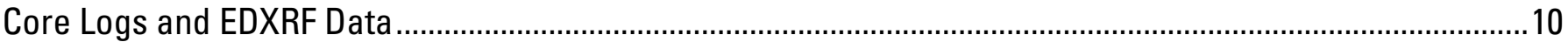

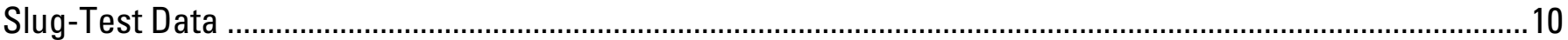

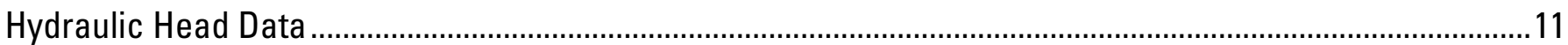

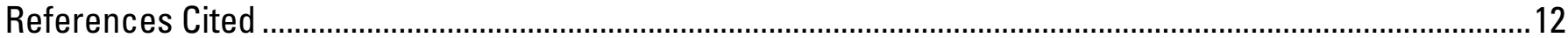

\section{Figures}

1. Location of Prospect Gulch in the upper Animas River watershed.......................................................................14

2. Boart Longyear Delta Base 540 drilling rig operated by Spectrum Exploration at upper elevation hole in Prospect

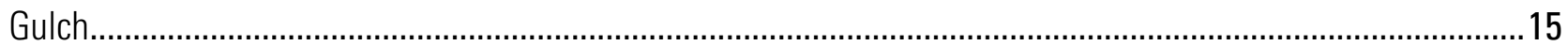

3. Locations of wells and piezometers in and around Prospect Gulch..................................................................... 16

4. Locations of wells and piezometers in Prospect Gulch, middle and upper elevations...............................................17

5. Locations of wells and piezometers in and around Prospect Gulch, lower elevations ..............................................18

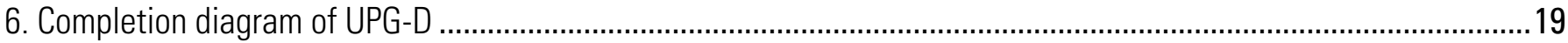

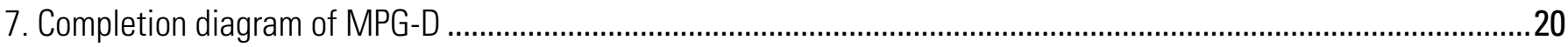

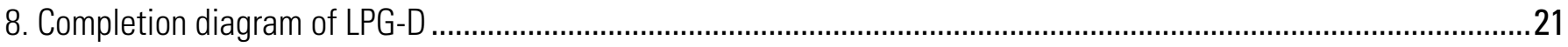

9. Geoprobe model 5410D rig near the mouth of Prospect Gulch (GPPG-10) operated by the U.S. Geological Survey under Bureau of Land Management contract ..........................................................................................22

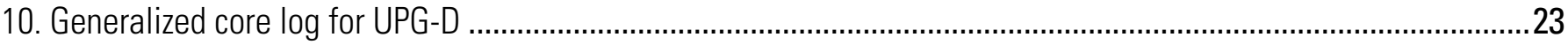

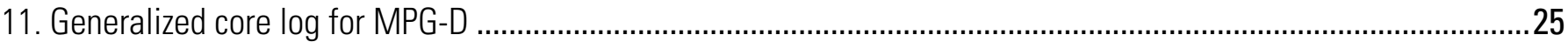

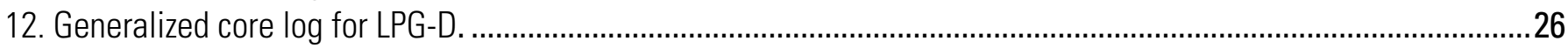

\section{Tables}

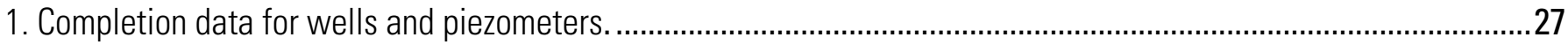

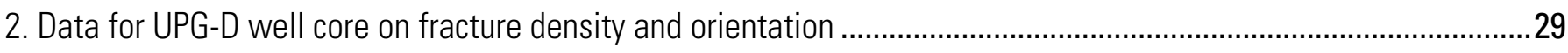

3. Data for MPG-D well core on fracture density and orientation. ............................................................................30

4. Data for LPG-D well core on fracture density and orientation...........................................................................

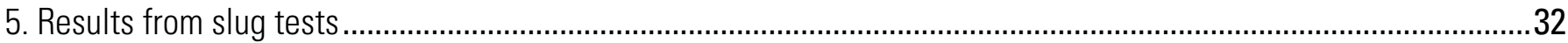




\section{Appendix Files}

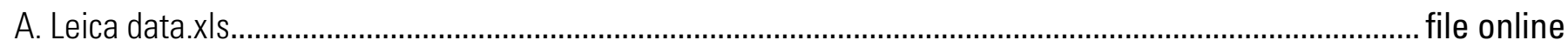

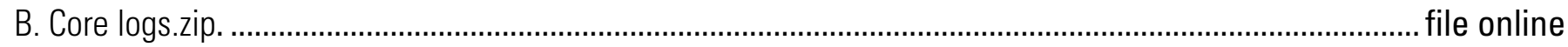

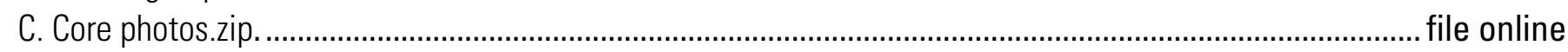

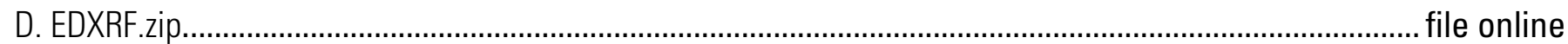

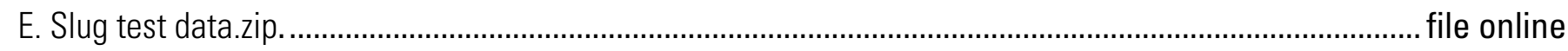

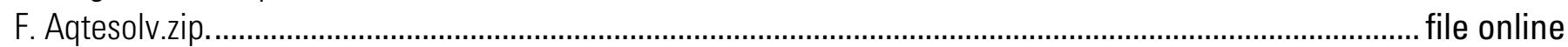

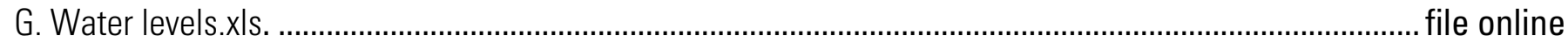




\section{Conversion Factors}

\section{Inch/Pound to SI}

\begin{tabular}{lcl}
\hline \multicolumn{1}{c}{ Multiply } & By & \multicolumn{1}{c}{ To obtain } \\
\hline Length & & \\
\hline inch & 2.54 & centimeter $(\mathrm{cm})$ \\
inch & 25.4 & millimeter $(\mathrm{mm})$ \\
foot (ft) & 0.3048 & meter $(\mathrm{m})$ \\
mile $(\mathrm{mi})$ & 1.609 & kilometer $(\mathrm{km})$ \\
\hline
\end{tabular}

\section{SI to Inch/Pound}

\begin{tabular}{lll}
\hline \multicolumn{1}{c}{ Multiply } & \multicolumn{1}{c}{ By } & \multicolumn{1}{c}{ To obtain } \\
\hline Length & & \\
\hline centimeter $(\mathrm{cm})$ & 0.3937 & inch \\
millimeter $(\mathrm{mm})$ & 0.03937 & inch \\
meter $(\mathrm{m})$ & 3.281 & foot $(\mathrm{ft})$ \\
meters per second $(\mathrm{m} / \mathrm{s})$ & 3.281 & feet per second \\
kilometer $(\mathrm{km})$ & 0.6214 & mile (mi) \\
\hline
\end{tabular}

Temperature in degrees Celsius $\left({ }^{\circ} \mathrm{C}\right)$ may be converted to degrees Fahrenheit $\left({ }^{\circ} \mathrm{F}\right)$ as follows: ${ }^{\circ} \mathrm{F}=\left(1.8 \mathrm{x}^{\circ} \mathrm{C}\right)+32$

Temperature in degrees Fahrenheit $\left({ }^{\circ} \mathrm{F}\right)$ may be converted to degrees Celsius $\left({ }^{\circ} \mathrm{C}\right)$ as follows: ${ }^{\circ} \mathrm{C}=\left({ }^{\circ} \mathrm{F}-32\right) / 1.8$

Vertical coordinate information is referenced to the North American Vertical Datum of 1929 (NAVD 29). Horizontal coordinate information is referenced to the North American Datum of 1927 (NAD 27). 


\title{
Completion Reports, Core Logs, and Hydrogeologic Data from Wells and Piezometers in Prospect Gulch, San Juan County, Colorado
}

\author{
By Raymond H. Johnson and Douglas Yager'
}

\begin{abstract}
In the late nineteenth century, San Juan County, Colorado, was the center of a metal mining boom in the San Juan Mountains. Although most mining activity ceased by the 1990s, the effects of historical mining continue to contribute metals to ground water and surface water. Previous research by the U.S. Geological Survey identified ground-water discharge as a significant pathway for the loading of metals to surface water from both acidmine drainage and acid-rock drainage. In an effort to understand the ground-water flow system in the upper Animas River watershed, Prospect Gulch was selected for further study because of the amount of previous data provided in and around that particular watershed. In support of this ground-water research effort, wells and piezometers were installed to allow for coring during installation, subsurface hydrologic testing, and the monitoring of ground-water hydraulic heads and geochemistry. This report summarizes the data that were collected during and after the installation of these wells and piezometers and includes (1) subsurface completion details, (2) locations and elevations, (3) geologic logs and elemental data, (4) slug test data for the estimation of subsurface hydraulic conductivities, and (5) hydraulic head data.
\end{abstract}

\section{Introduction}

In the late nineteenth century, San Juan County, Colorado, was the center of a metal mining boom in the San Juan Mountains. Although most mining activity ceased by the 1990s, the effects of historical mining continue to contribute metals to ground water and surface water. These increased metal concentrations degrade stream-water quality and are toxic to fish and other aquatic organisms. As a result, viable fish and aquatic habitat is now more limited than what existed before mining (Besser and others, in press). Since the 1990s, the local economic base has shifted away from hard-rock mining toward tourism with a focus on recreational opportunities. Increased population downstream also has increased the demand for clean water. While streams in this area have low $\mathrm{pH}$ and elevated metal loads due to acid-rock drainage, the influence of acid-mine drainage due to historical mining activities has degraded preexisting ground-water and surface-water quality (Church and others, in press). Determining the ground-water flow and associated dissolved-metal transport is critical to protecting ground-water and surface-water resources, determining the influence of acid-mine drainage compared to versus preexisting acid-rock drainage, and providing sensible remedial options.

${ }^{1}$ U.S. Geological Survey, Minerals Resources Team, Denver, Colorado 
Much of the San Juan Mountains is influenced by historical mining, and many surface-water samples (along with other data) have been collected in the upper Animas River watershed (fig. 1) by the U.S. Geological Survey (Church and others, in press; http://amli.usgs.gov/reports/). Three goals of this watershed characterization project were to (1) characterize the surface-water quality, (2) identify abandoned mines that contribute the greatest metal loads to surrounding surface waters, and (3) determine premining water quality. The ultimate objective was to provide the necessary scientific information for public land managers to select effective remedial approaches that would improve watershed quality. Ground-water discharge has been identified as a significant pathway for the loading of metals to surface water from both acid-mine drainage and from acid-rock drainage (Church and others, in press; Mast and others, in press; Kimball and others, 2002; Kimball and others, in press). Understanding the ground-water flow and dissolved metal transport is essential in determining whether sampled metal loads to streams are related to acid-mine drainage or acidrock drainage, and thus, whether or not an identified source of metal loading should be remediated.

In an effort to understand the ground-water flow system in the upper Animas River watershed, Prospect Gulch (fig. 1) was selected for further study because of the amount of data provided in and around that particular watershed (Church and others, in press), including stream tracer studies (Kimball and others, 2002; Wirt and others, 1999, 2001) and detailed maps of hydrothermal alteration (Bove and others, in press). In addition, many of the inactive mines within Prospect Gulch are on land managed by the Bureau of Land Management (BLM). An understanding of the ground-water flow system is critical in assisting them with their remedial efforts. In support of this ground-water research effort, wells and piezometers were installed to allow for coring during installation, subsurface hydrologic testing, and the monitoring of ground-water hydraulic heads and geochemistry. This report summarizes the data that were collected during and after the installation of these wells and piezometers and includes (1) subsurface completion details, (2) locations and elevations, (3) geologic logs and elemental data, (4) slug test data for the estimation of subsurface hydraulic conductivities, and (5) hydraulic head data.

\section{Geologic Setting}

The predominant rock types in the Prospect Gulch study area consist of intermediateto felsic-composition igneous rocks. These rocks formed following formation of the 28.2-Ma San Juan caldera, coincident with and (or) postdating formation of the 27.8-Ma Silverton caldera (Yager and Bove, 2002). Intermediate-composition lava flows and minor volcaniclastic sedimentary rocks that were deposited on the flanks of central vent volcanoes predominate this igneous sequence and are part of the Silverton Volcanics described by Lipman and others (1973). Silverton Volcanics lavas and volcaniclastic sediments shed from the adjacent volcanoes infilled the San Juan caldera volcanic depression to nearly a kilometer in thickness over an approximately 14-km-diameter area. Primary igneous minerals of the Silverton Volcanics intermediate-composition porphyritic lavas include, in relative order of abundance, plagioclase, quartz, hornblende, pyroxene, \pm biotite, and opaque oxide minerals.

A regional propylitic alteration event affected much of the study area following caldera formation and was contemporaneous with Silverton Volcanics deposition (Burbank, 1960). The propylitic alteration formed as the large thickness of lavas that infilled the San Juan caldera cooled and degassed, altering the primary igneous mineral assemblage to a secondary assemblage containing chlorite, \pm epidote, \pm calcite, \pm pyrite, fine-grained 
muscovite, and iron oxide minerals. This propylitic assemblage was shown to have some acid-neutralizing capacity where it was not more intensely altered by later hydrothermal alteration events (Yager and others, 2005).

Prospect Gulch is located on the margin of the historic Red Mountain mining district, where ore deposits of silver, copper, lead, and zinc sulfides were discovered in 1881 (Burbank, 1947) and is located near the northwest structural margins of the San Juan and Silverton calderas. This area is the locus for several small-volume plugs and dikes of dacite to rhyolite composition that intruded along the structural margins of the calderas, long after caldera activity ceased. Isotopic ages of intrusions near Prospect Gulch indicate that they also formed several million years after eruption of the intermediate-composition Silverton Volcanics lavas during the Miocene Epoch, which are thought to have provided the heat source for the hydrothermal system that was responsible for mineralization and associated alteration in and adjacent to the Red Mountain mining district (Lipman and others, 1976; Bove and others, 2001).

Several alteration types formed contemporaneously with or shortly after felsic intrusive activity at $21 \mathrm{Ma}$, overprinting the regional propylitic assemblage and locally eliminating any acid-neutralizing capacity while introducing acid-generating minerals, especially pyrite. These assemblages are particularly evident in the vicinity of Red Mountain \#3 (fig. 1) whose slopes drain into Prospect Gulch. The summit and slopes of Red Mountain \#3 are stained with secondary mineral coatings that are caused mainly by the oxidation and weathering of pyrite. The mineral coatings impart spectacular hues of red, yellow, and brown, which led to the naming of the Red Mountains.

The geology of the area and types of alteration vary substantially from north to south across the Prospect Gulch subbasin (Bove and others, in press). The majority of intensely altered terrain is exposed along the northern part of the subbasin on south-facing slopes along and beneath the ridge that separates Dry Gulch from Prospect Gulch (see fig. 3). Acid sulfate mineralization is exposed near Red Mountain \#3 and is characterized by a high sulfidization mineral assemblage that includes quartz, alunite, pyrophyllite (QAP assemblage), and pyrite. Pervasive silicification accompanied the acid sulfate alteration where it forms highly resistant ridges such as those exposed on Red Mountain \#3. Poorly indurated and more easily weathered argillic (ARG assemblage) alteration occurs on the margins of the quartz-alunitepyrophyllite assemblage (QAP assemblage); dickite (a waxy clay mineral in outcrop) is commonly associated with this assemblage. Areas of pervasive quartz-sericite-pyrite (QSP assemblage) alteration, locally containing $10-20$ volume percent pyrite where not oxidized, is the largest alteration type exposed in Prospect Gulch. The QSP assemblage commonly crops out topographically below or adjacent to the QAP and ARG assemblages. Similar to the ARG assemblage, the QSP assemblage is more readily weathered than the QAP assemblage. Surficial deposits including debris cones and talus that have formed below Red Mountain \#3 incorporate clasts of the upslope QAP, ARG, and QSP assemblages.

In the southern part and lower one-third of Prospect Gulch, regional propylitic alteration dominates, although it is locally overprinted by narrow, more intensely altered zones of QAP and QSP assemblages that are exposed in northeast-trending gulleys in the upper part of the subbasin that drain toward the north into Prospect Gulch. Locally, surficial deposits involving mainly propylitically altered clasts, whose source is located along the ridge that separates Georgia Gulch from Prospect Gulch (see fig. 3), are volumetrically important.

A general structural fabric is evident in and around Prospect Gulch based on interpretation of mapped veins (D.J. Bove, unpub. data, 2005; Bove and others, in press). Northwest-, north-, and northeast-trending veins are evident along with another prominent set 
of east-trending veins. These veins may have formed along existing faults or formed contemporaneously with mineralization along structural zones of weakness. Definitive evidence at the surface of faulting related to vein emplacement, however, is sparse. Eastwest-trending veins are not as common as their north-trending counterparts, but they do occur. Major structures, if present, are obscured largely by the intense alteration that has affected much of the northern subbasin. Additional detailed mapping is needed to determine offset of marker horizons along faults (if any are preserved) such as interbedded volcaniclastic units within the Silverton Volcanics.

\section{Hydrologic Setting}

The stream in Prospect Gulch is approximately $2.4 \mathrm{~km}$ in length with an elevation change of $800 \mathrm{~m}$. Average annual precipitation is about $114 \mathrm{~cm}$ with $94 \mathrm{~cm}$ occurring as snowfall (Wirt an others, 2001). As a result, most recharge into the ground-water system occurs in late May and early June during the spring snowmelt. Late June through September is dominated by summer thunderstorms, producing rainfall that provides additional groundwater recharge (Wirt and others, 1999). Snow generally covers the ground surface in most of Prospect Gulch from October through early May, preventing any significant recharge to the ground water-system.

\section{Well and Piezometer Completion Data}

In August and September of 2004, three wells and one piezometer were drilled by Spectrum Exploration using a Boart Longyear Delta Base 540 drilling rig (fig. 2). The locations and elevations of these wells and piezometer are in table 1 and figures $3-5$. Initial well drilling was started using a rotary core bit with a casing advancer to get through unconsolidated material and highly fractured, weathered bedrock. All drilling depths are reported in feet since these were the units provided by the contractor. In well UPG-D the 22$\mathrm{ft}$ length of casing was left in the ground, whereas the surface casing was removed from wells MPG-D and LPG-D upon completion. Split spoon samples were collected when using the rotary core bit. Competent bedrock was drilled using a diamond-encrusted drill bit, and core was collected using a wireline system. The resulting drill hole was 3.875 inches in diameter. Downhole drilling equipment was cooled using direct water circulation, where the water was drawn from Prospect Gulch near each drilling location. Multilevel sample points were installed within each borehole (UPG-D, MPG-D, and LPG-D) as shown in figures 6-8, respectively. Well UPG-D remained an open borehole from the date of drilling completion (August 20, 2004) until it was completed with multilevel sampling points on July 11, 2005. As indicated in table 1, screened intervals were completed using 0.010-inch, preslotted, manufactured PVC pipe, or hand-slotted PVC pipe, or a BARCAD device. The BARCAD device is produced by BESST, Inc., and provides a means for sampling deep well locations by using compressed gas. The BARCAD device has a check valve that closes under pressure to allow water sampling but remains open under normal conditions to allow for ambient hydraulic-head measurements.

During the same time period, 15 piezometers were installed at the base of Prospect Gulch by the USGS New Mexico Water Science Center under contract with the BLM. These installations were completed using a Geoprobe model 5410D hydraulically powered direct push drilling rig (fig. 9). This system drove a 2.125-inch drill stem into the subsurface until refusal, which was assumed to be cemented alluvial material or bedrock. A well point or 
piezometer was completed within this drill stem with 10/20 mesh sand filled to $2 \mathrm{ft}$ below ground surface. The remaining $2 \mathrm{ft}$ was filled with bentonite pellets. In addition, five piezometers were installed with the same Geoprobe rig and the same completion procedure by the BLM in the area of the Lark Mine (fig. 4, LGP series). The locations of all of these "Geoprobe holes" are shown in figures 3 - 5. Installation details and locations are in table 1. Latitude, longitude, and elevation for all points listed in table 1 were measured using a Leica GPS1200 system with accuracies generally on the order of $\pm 0.02 \mathrm{~m}$. The original location and elevation data file is included as Appendix A.

\section{Core Logs and EDXRF Data}

Core $\operatorname{logs}$ are shown in the following figures: UPG-D in figure 10, MPG-D in figure 11, and LPG-D in figure 12. The original core log files are in Appendix B and photos of all of the cores are in Appendix C. Data on fracture density and orientation for all of the well cores are in tables $2-4$. No coring was completed in any of the piezometer holes.

Energy dispersive $\mathrm{x}$-ray fluorescence (EDXRF) analyses were acquired on several depth intervals of each core while in the field (Appendix D). These data were acquired by using a portable EDXRF Niton ${ }^{\mathrm{TM}}$ instrument. EDXRF analysis is a nondestructive technique that is useful for simultaneous acquisition of a suite of elements over a broad spectral energyexcitation range. The Niton ${ }^{\mathrm{TM}}$ instrument uses both $\mathrm{Cd}^{109}$ and $\mathrm{Am}^{241}$ radioisotope $\mathrm{x}$-ray sources; each source is used to excite a suite of elements that have lower x-ray excitation energy (lower atomic number) than the respective radioisotope used as an excitation source. Data acquired are semiquantitative, especially in the field, where the rock matrix analyzed is heterogeneous and the silicon-lithium X-ray detector in the Niton ${ }^{\mathrm{TM}}$ instrument is at air temperature rather than cooled by liquid nitrogen, as is common in laboratory applications. Higher analytical accuracy and precision is possible with EDXRF units when homogeneous matrices such as rock powders are available for analyses. Nonetheless, the Niton ${ }^{\mathrm{TM}}$ field EDXRF instrument is useful for providing a semiquantitative assessment of selected elements and is useful as a geochemical element screening tool.

Elements that typically are determined with a high precision and accuracy using the $\mathrm{Cd}^{109}$ source include rubidium, strontium, zirconium, and zinc. Analyses for iron, lead, arsenic, molybdenum, and manganese also are reported in Appendix C. Samples with low to intermediate iron abundances are the most accurate. Spectral overlaps must be evaluated when using uncorrected arsenic and lead concentration data, and robust spectral deconvolution algorithms are needed when lead and arsenic are both present in a sample. Molybdenum concentrations by EDXRF, especially at low concentrations as are typical in Prospect Gulch core samples, are at best considered semiquantitative. Using the $\mathrm{Am}^{241}$ source, barium is the only element in high enough concentration to determine results with reasonable precision and accuracy.

\section{Slug-Test Data}

Slug tests were completed in all piezometer and well points during the period of June $23-27,2005$. These tests were completed by inserting a 0.25 -inch polypropylene line below the water table along with a pressure transducer. The water in the casing above the end of the polypropylene line was air-lifted using nitrogen (slug change in water level), and the changing water levels were measured with the pressure transducer. The pressure transducer system used a Geokon 4500C vibrating-wire pressure transducer paired with a Geokon 8001 single- 
channel data logger. All slug-test results were analyzed using Aqtesolv for Windows version 3.50 Professional by HydroSOLVE, Inc., and followed the procedures for choosing slug test analysis methods discussed in Butler (1997). The slug-test data and individual wellcompletion data used for the analyses are in Appendix E. In the analyses, the diameter of the air tube and the transducer wire ( $9 \mathrm{~mm}$ of solid "equipment") were accounted for in calculating the inner diameter of the casing. All Aqtesolv files are in Appendix F. All tests were analyzed using the Kansas Geological Survey (KGS) model for the analysis of slug tests (Hyder and others, 1994; Butler, 1997), and the results are in table 5. Confined conditions were used only for the lower elevation well (LPG-D). All slug-test results were also analyzed with the solution methods of Hvorslev (1951) and Bouwer and Rice (1976), which provided very similar results in all cases.

Slug-test results indicate three general areas of similar hydraulic conductivities, which are (1) near-surface alluvial/colluvial material, (2) bedrock, and (3) alluvial/colluvial material in the middle of Prospect Gulch. The majority of piezometers (all GPPG wells, MPG-D-13 and LPG-D-25) are completed in the near-surface alluvial/colluvial material and provide a range of hydraulic conductivities from $7.9 \times 10^{-7} \mathrm{~m} / \mathrm{s}$ to $1.2 \times 10^{-5} \mathrm{~m} / \mathrm{s}$. These results are typical for shallow deposits with a large variation in depositional environment. Of these piezometers, GPPG-12 $\left(7.9 \times 10^{-7} \mathrm{~m} / \mathrm{s}\right)$ is very shallow and was completed in clayey/silty stream overbank deposits in a marshy area. GPPG-8 $\left(1.2 \times 10^{-5} \mathrm{~m} / \mathrm{s}\right)$ was completed in an abandoned stream-channel deposit. A representative value for these alluvial/colluvial materials that overlie bedrock is approximately $5 \times 10^{-6} \mathrm{~m} / \mathrm{s}$. The two bedrock monitoring points, LPG-86 and LPG-159, had hydraulic conductivities of $4.8 \times 10^{-7} \mathrm{~m} / \mathrm{s}$ and $7.8 \times 10^{-7}$ $\mathrm{m} / \mathrm{s}$, respectively, for a representative value of approximately $5 \times 10^{-7} \mathrm{~m} / \mathrm{s}$. The alluvial/colluvial material in the middle of Prospect Gulch (LGP-3 and LGP-5) is classified separately, with hydraulic conductivities of $3.4 \times 10^{-7} \mathrm{~m} / \mathrm{s}$ and $7.9 \times 10^{-8} \mathrm{~m} / \mathrm{s}$, respectively, because of its lower hydraulic conductivity due to higher silt/clay contents associated with the very hydrothermally altered source rock.

\section{Hydraulic Head Data}

Hydraulic head data from all measured wells and piezometers from installation through June, 2006, are in Appendix G. Because of the limited time period of measurement and limited number of measurement locations in the interior of Prospect Gulch, a discussion of the data is presented below in lieu of graphs and hydraulic-head elevation maps.

Well UPG-D: The upper elevation well (UPG-D) shows the greatest variation in hydraulic heads during the time that this was an open borehole. This hole was dry in the summer of 2004, except for a brief period after a precipitation event in September 2004. In the spring of 2005, the hydraulic head was at $37 \mathrm{ft}$ below ground surface. As a multilevel completion, this well shows a very strong downward gradient (hydraulic-head elevation change divided by monitoring-point elevation change $=0.87$ ).

Well MPG-S: The shallow piezometer (MPG-S) near the stream in the middle of Prospect Gulch shows relatively stable water levels because it is very close to the stream.

Well MPG-D: The deep middle elevation well (MPG-D) consistently shows a perched water-table system in the colluvial material above the fractured bedrock (MPG-D13). The colluvial material at depth (MPG-D-51) is commonly unsaturated, as is the fractured bedrock just below the colluvial material (MPG-D-110). A deeper water table occurs with depth at approximately $165 \mathrm{ft}$ (MPG-D-173) with seasonal changes in saturated/unsaturated 
conditions. The deeper ground-water system appears to have a delayed response to recharge during the year, possibly because it is being recharged by snowmelt at higher elevations. The shallow colluvial system responds very quickly to recharge events and is seasonally variable (MPG-D-13 and LGP-1 through LGP-5).

Well LPG-D and piezometers: At the base of Prospect Gulch, many of the piezometers are measuring deep ground water that is discharging to Cement Creek. Because this is a discharge zone, seasonal variations in hydraulic head are minimal. However, GPPG$8,9,10$, and 11 do appear to measure shallow water from seasonal recharge events because these points are all in the alluvial material close to the mouth of Prospect Gulch. In the lower elevation well (LPG), there is a strong upward gradient $(0.19)$ representing a confined groundwater discharge zone in the bedrock.

\section{References Cited}

Besser, J.M., Finger, S.E., and Church, S.E., in press, Impacts of historical mining on aquatic ecosystems-An ecological risk assessment, in Church, S.E., von Guerard, Paul, and Finger, S.E., eds., Integrated investigations of environmental effects of historical mining in the Animas River watershed, San Juan County, Colorado: U.S. Geological Survey Professional Paper 1651.

Bouwer, H., and Rice, R.C., 1976, A slug test method for determining hydraulic conductivity of unconfined aquifers with completely or partially penetrating wells: Water Resources Research, v. 12, no. 3, p. 423-428.

Bove, D.J., Hon, K., Budding, K.E., Slack, J.F., Snee, L.W., and Yeoman, R.A., 2001, Geochronology and geology of late Oligocene through Miocene volcanism and mineralization in the western San Juan Mountains, Colorado: U.S. Geological Survey Professional Paper 1642, 30 p. (http://pubs.usgs.gov/of/1999/ofr-99-0347/).

Bove, D.J., Mast, M.A., Dalton, J.B., Wright, W.G., and Yager, D.B, in press, Major styles of mineralization and hydrothermal alteration and related solid- and aqueous-phase geochemical signatures, in Church, S.E., von Guerard, Paul, and Finger, S.E., eds., Integrated investigations of environmental effects of historical mining in the Animas River Watershed, San Juan County, Colorado: U.S. Geological Survey Professional Paper 1651.

Burbank, W.S., 1947, Red Mountain District, Ouray County in Vanderwilt, J.W., ed., Mineral resources of Colorado: State of Colorado, Mineral Resources Board.

Burbank, W.S., 1960, Pre-ore propylitization, Silverton Caldera, Colorado, in Geological Survey Research 1960: U.S. Geological Survey Professional Paper 400-B, article 6, p. B12-B13.

Butler, J.J., Jr., 1997, The design, performance, and analysis of slug tests: Lewis Publishers, CRC Press LLC, Boca Raton, Florida, 252 p.

Church, S.E., von Guerard, Paul, and Finger, S.E., eds., in press, Integrated investigations of environmental effects of historical mining in the Animas River Watershed, San Juan County, Colorado: U.S. Geological Survey Professional Paper 1651, 6 plates, 1 DVD.

Hyder, Z., Butler, J.J., Jr., McElwee, C.D., and Liu, W., 1994, Slug tests in partially penetrating wells: Water Resources Research, v. 30, no. 11, p. 2945-2957. 
Hvorslev, M.J., 1951, Time lag and soil permeability in ground-water observations, Bulletin No. 36: Waterways Experiment. Station Corps of Engineers, U.S. Army, Vicksburg, Mississippi, p. 1-50.

Kimball, B.A., Runkel, R.L., Walton-Day, K.W., and Bencala, K.E., 2002, Assessment of metal loads in watersheds affected by acid mine drainage by using tracer injection and synoptic sampling - Cement Creek, Colorado, USA: Applied Geochemistry, v. 17, p. 1183-1207.

Kimball, B.A., Walton-Day, Katherine, and Runkel, R.L., in press, Quantification of metal loading by tracer injection and synoptic sampling, 1996-2000, in Church, S.E., von Guerard, Paul, and Finger, S.E., eds., Integrated investigations of environmental effects of historical mining in the Animas River Watershed, San Juan County, Colorado: U.S. Geological Survey Professional Paper 1651.

Lipman, P.W., Steven, T.A., Luedke, R.G., and Burbank, W.S., 1973, Revised volcanic history of the San Juan, Uncompahgre, Silverton, and Lake City calderas in the western San Juan Mountains, Colorado: U.S. Geological Survey Journal of Research, v. 1, p. 627-642.

Lipman P.W., Fisher, W.S., Mehnert, H.H., Naeser, C.W., Luedke, R.G., and Steven, T.A., 1976, Multiple ages of mid-Tertiary mineralization and alteration in the western San Juan Mountains, Colorado: Economic Geology, v. 71, p. 571-588.

Mast, M.A., Verplanck, P.L., Wright, W.G., and Bove, D.J., in press, Characterization of background water quality, in Church, S.E., von Guerard, Paul, and Finger, S.E., eds., Integrated investigations of environmental effects of historical mining in the Animas River Watershed, San Juan County, Colorado: U.S. Geological Survey Professional Paper 1651.

Wirt, L., Leib, K.J., Bove, D.J., Mast, M.A., Evans, J.B., and Meeker, G.P., 1999, Determination of chemical-constituent loads during base-flow and storm-runoff conditions near historical mines in Prospect Gulch, upper Animas River watershed, southwestern Colorado: U.S. Geological Survey Open-File Report 99-159, 39 p.

Wirt, L., Leib, K.J., Bove, D., and Melick, R., 2001, Metal loading assessment of point and non-point sources in a small alpine sub-basin characterized by acid drainage-Prospect Gulch, upper Animas River watershed, Colorado: U.S. Geological Survey Open-File Report 2001-0258, 36 p.

Yager, D.B., and Bove, D.J., 2002, Generalized geologic map of part of the upper Animas River watershed and vicinity, Silverton, Colorado: U.S. Geological Survey Miscellaneous Field Studies Map MF-2377, scale 1:48,000.

Yager, D.B., McCafferty, A.E., Stanton, M.R., Diehl, S.F., Driscoll, R.L., Fey, D.L., and Sutley, S.J., 2005, Net acid production, acid neutralizing capacity, and associated geophysical, mineralogical, and geochemical characteristics of Animas River watershed rocks near Silverton, Colorado: U.S. Geological Survey Open-File Report 2005, 78 p. 


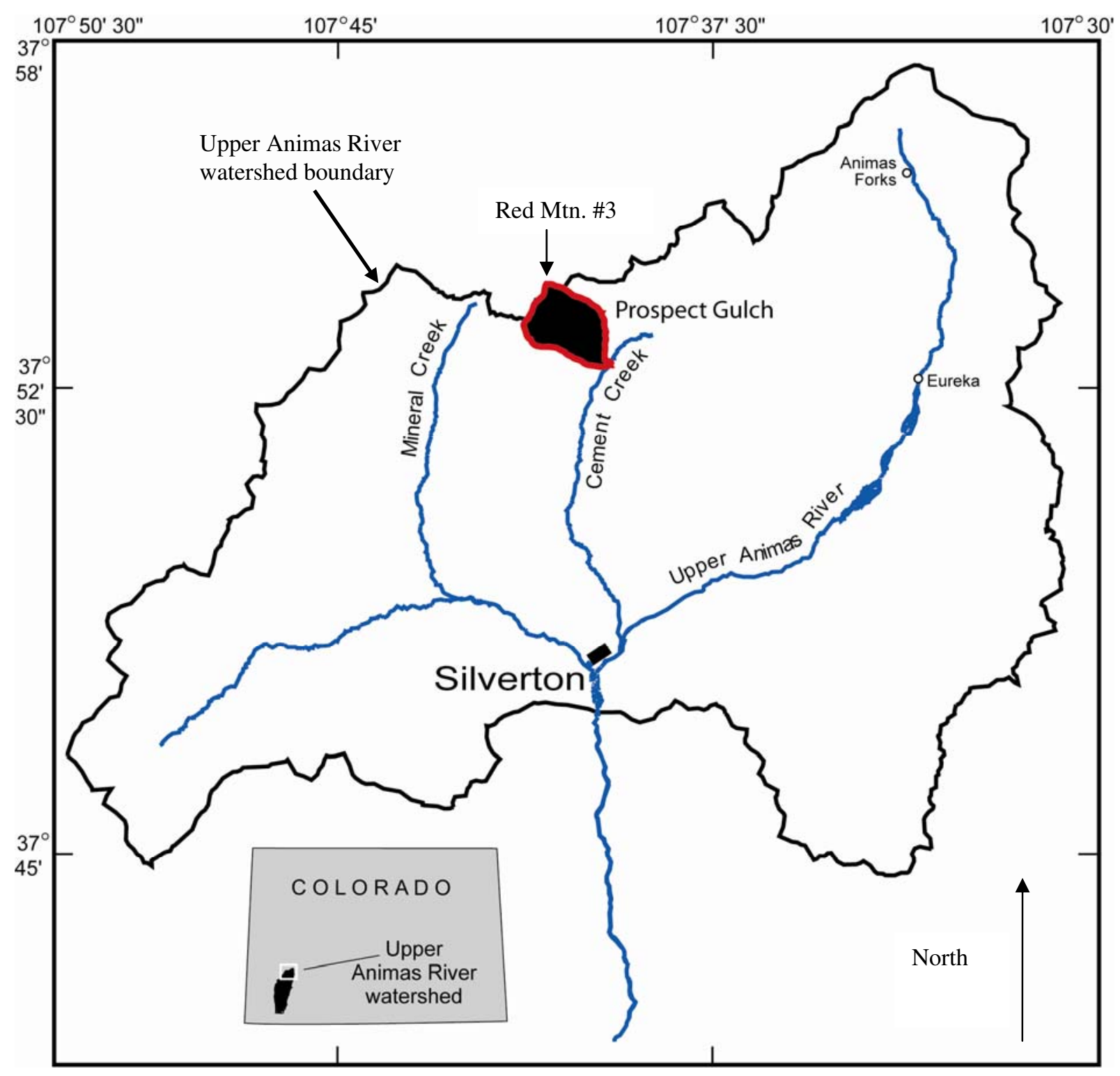

Figure 1. Location of Prospect Gulch in the upper Animas River watershed. 


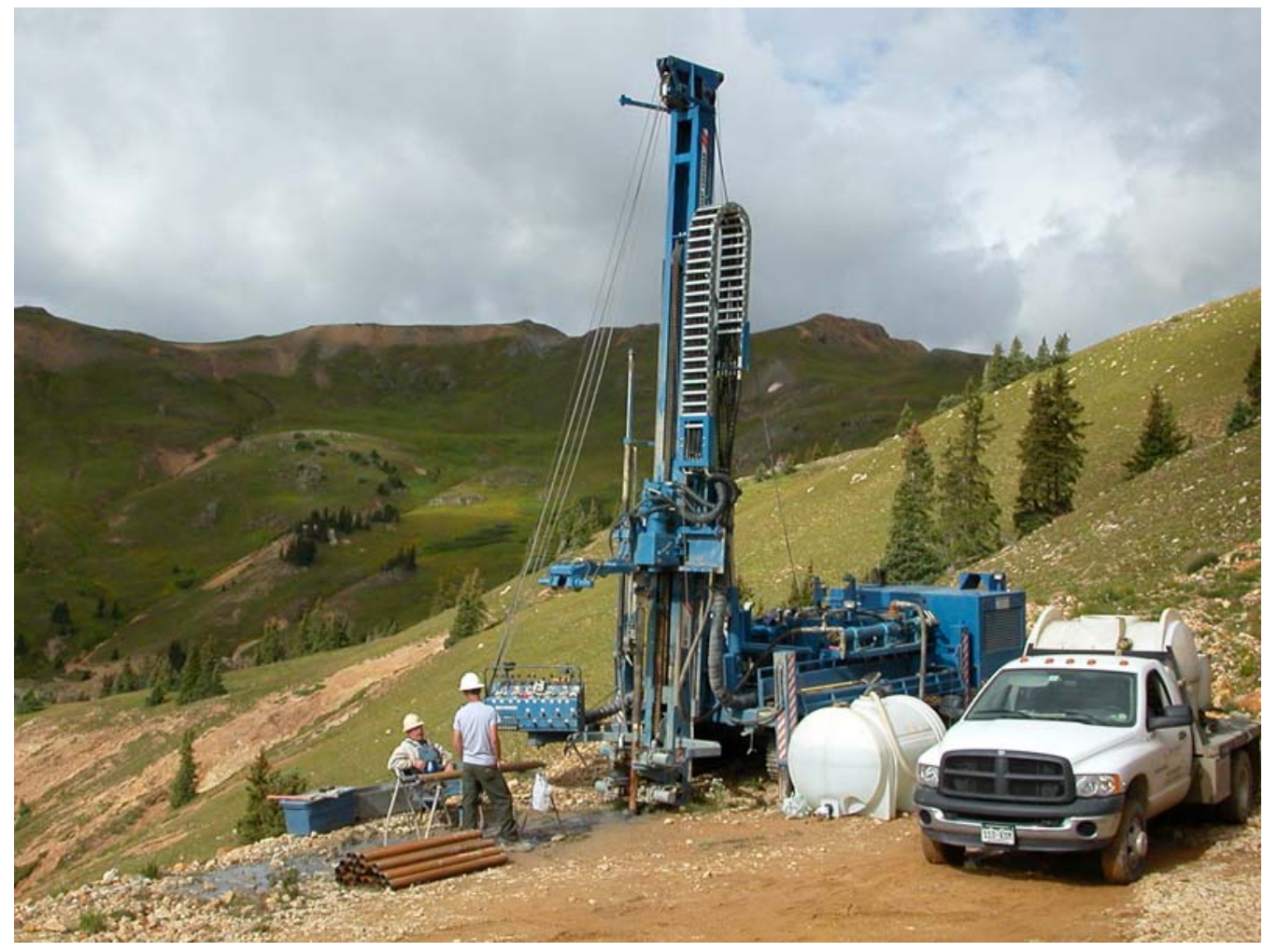

Figure 2. Boart Longyear Delta Base 540 drilling rig operated by Spectrum Exploration at upper elevation hole in Prospect Gulch. 


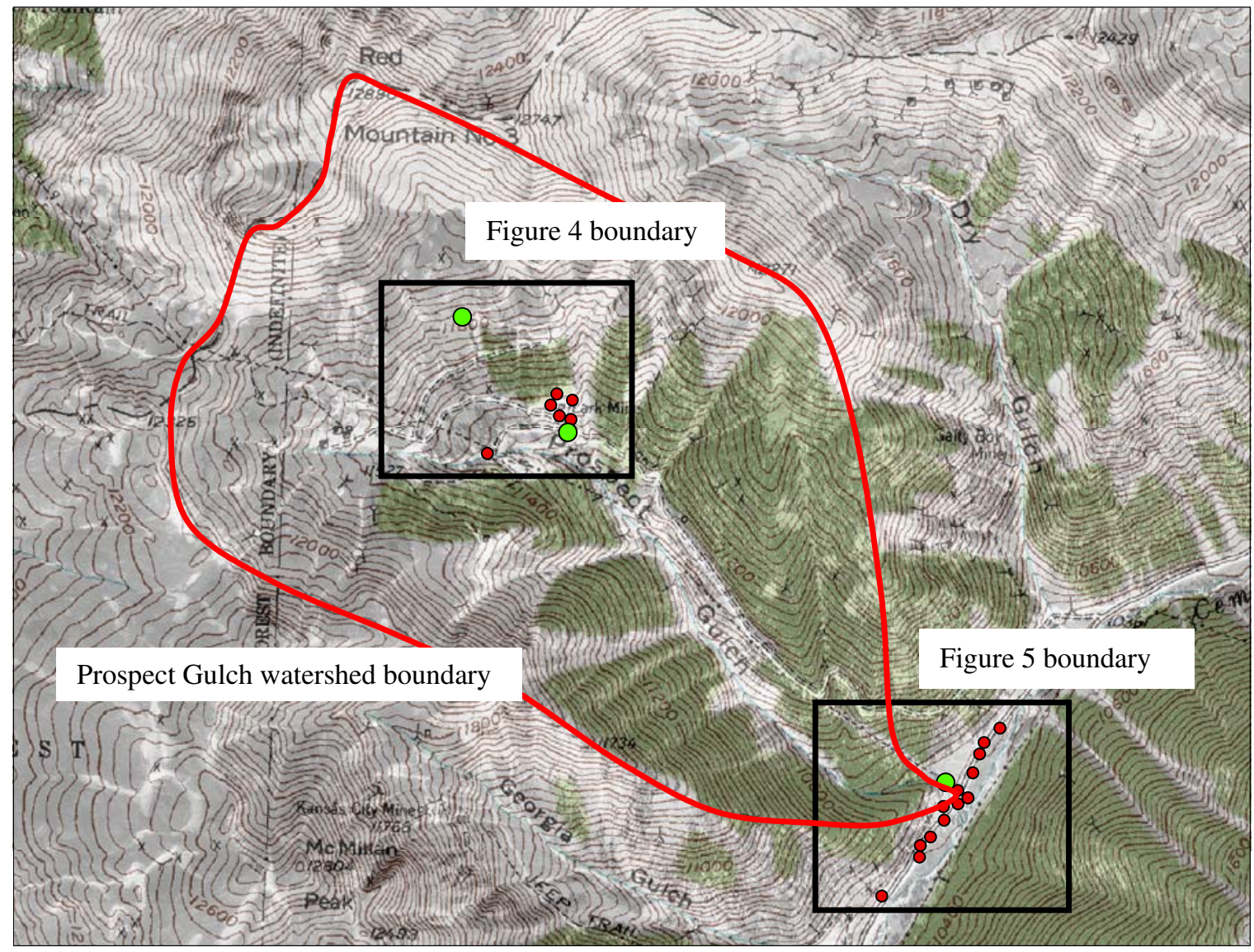

$\bigcirc$ Wells

Piezometers

Figure 3. Locations of wells and piezometers in and around Prospect Gulch. 


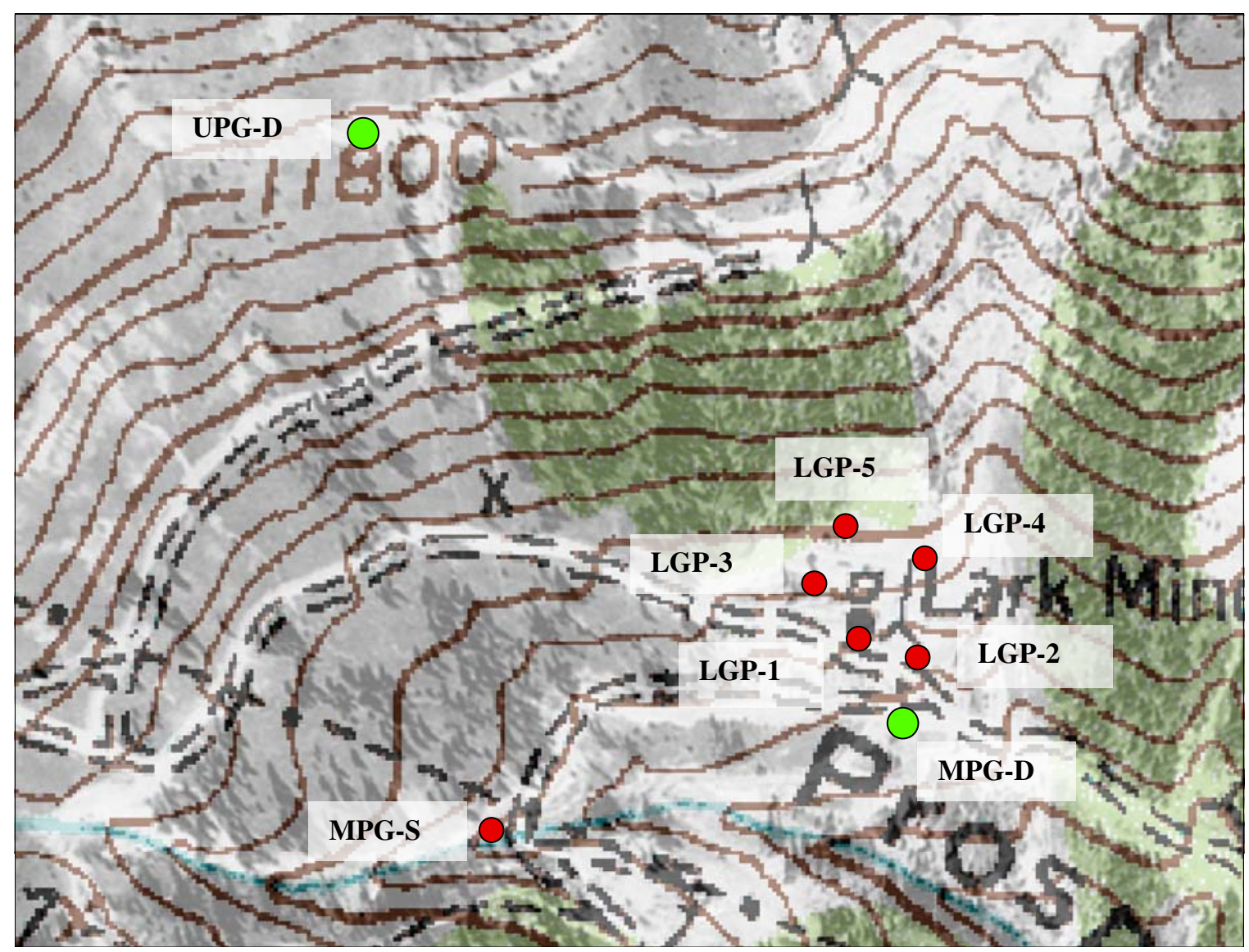

$\bigcirc$ Wells

Piezometers

Figure 4. Locations of wells and piezometers in Prospect Gulch, middle and upper elevations. 


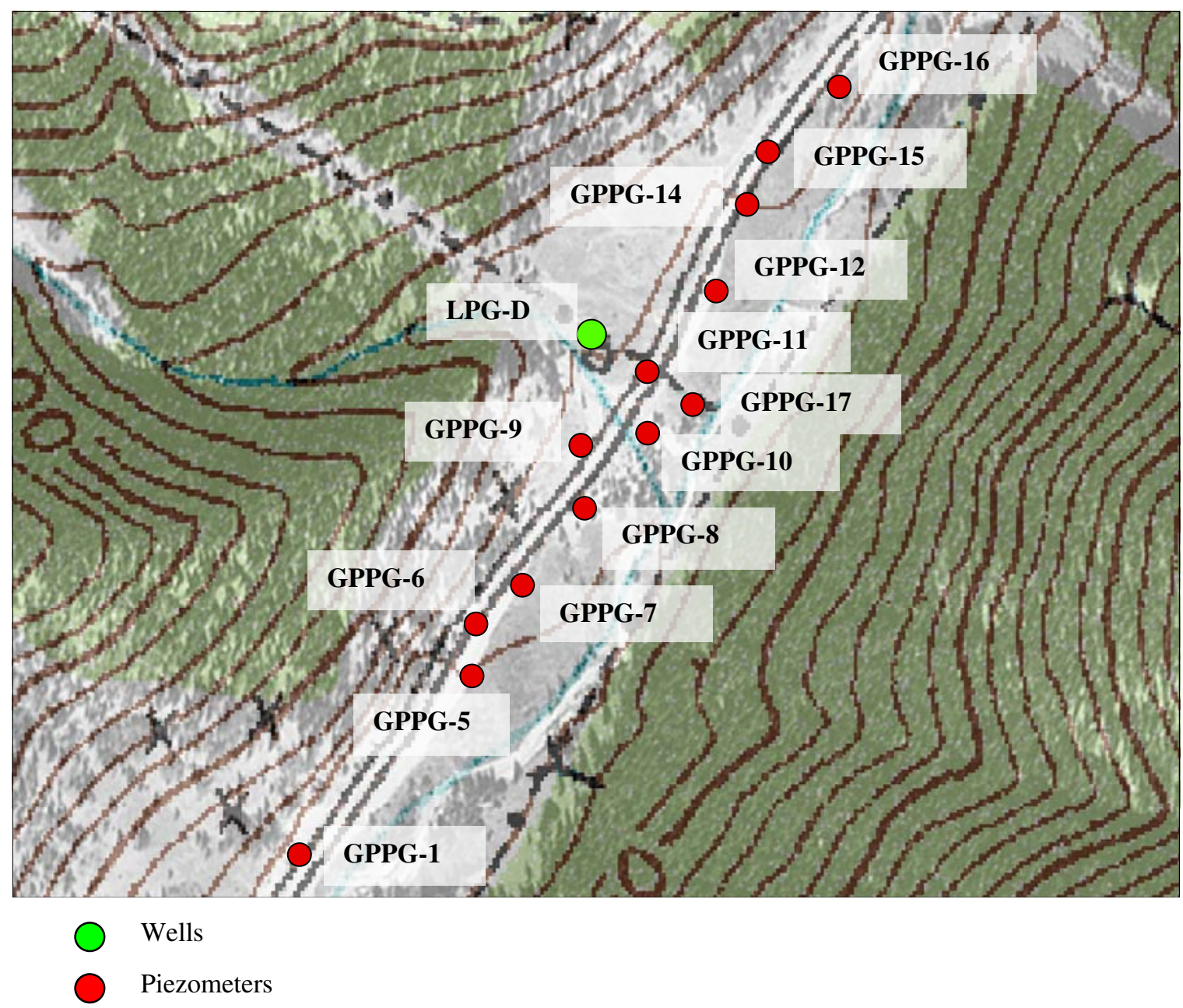

Figure 5. Locations of wells and piezometers in and around Prospect Gulch, lower elevations. 


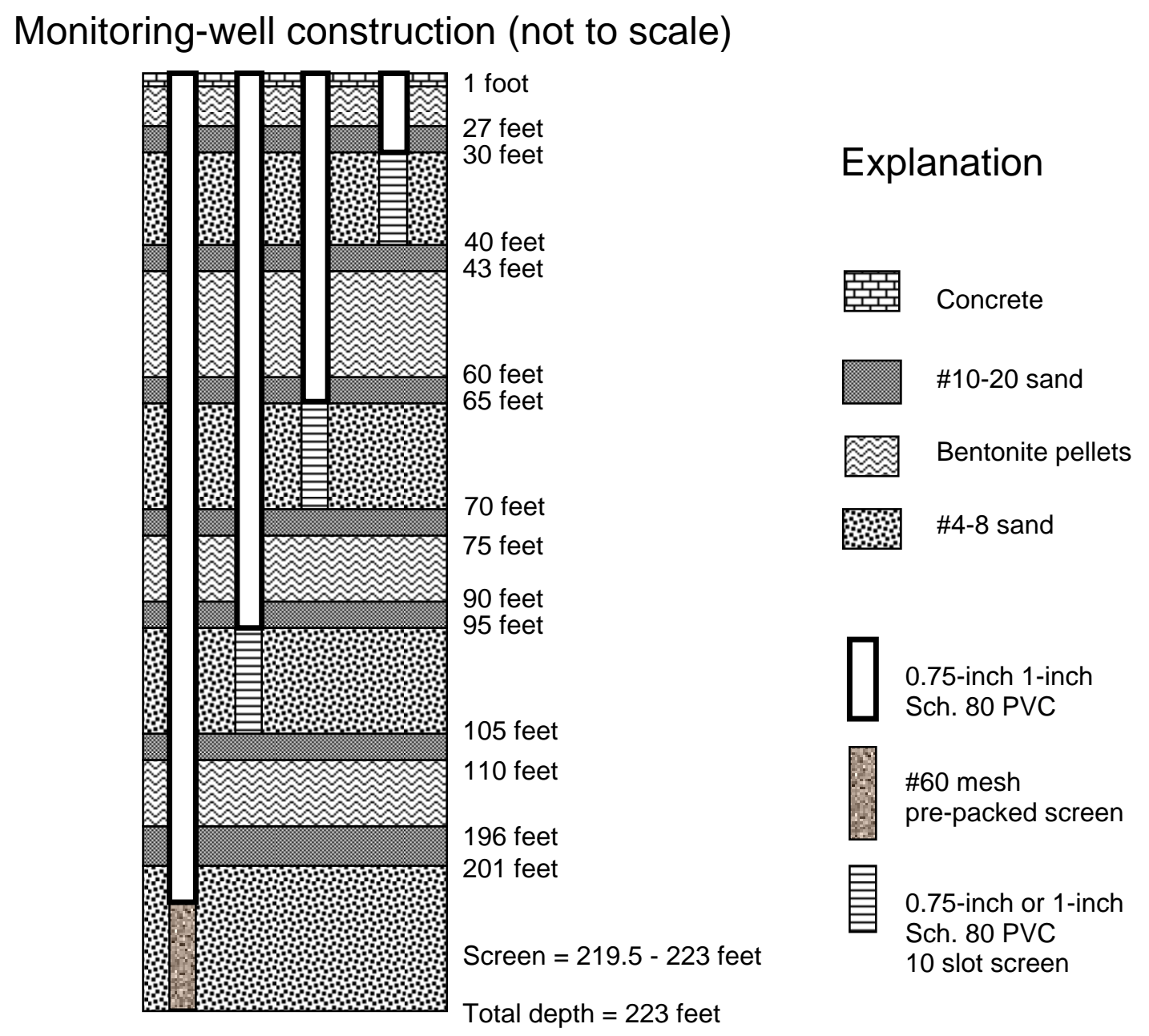

Figure 6. Completion diagram of UPG-D. 


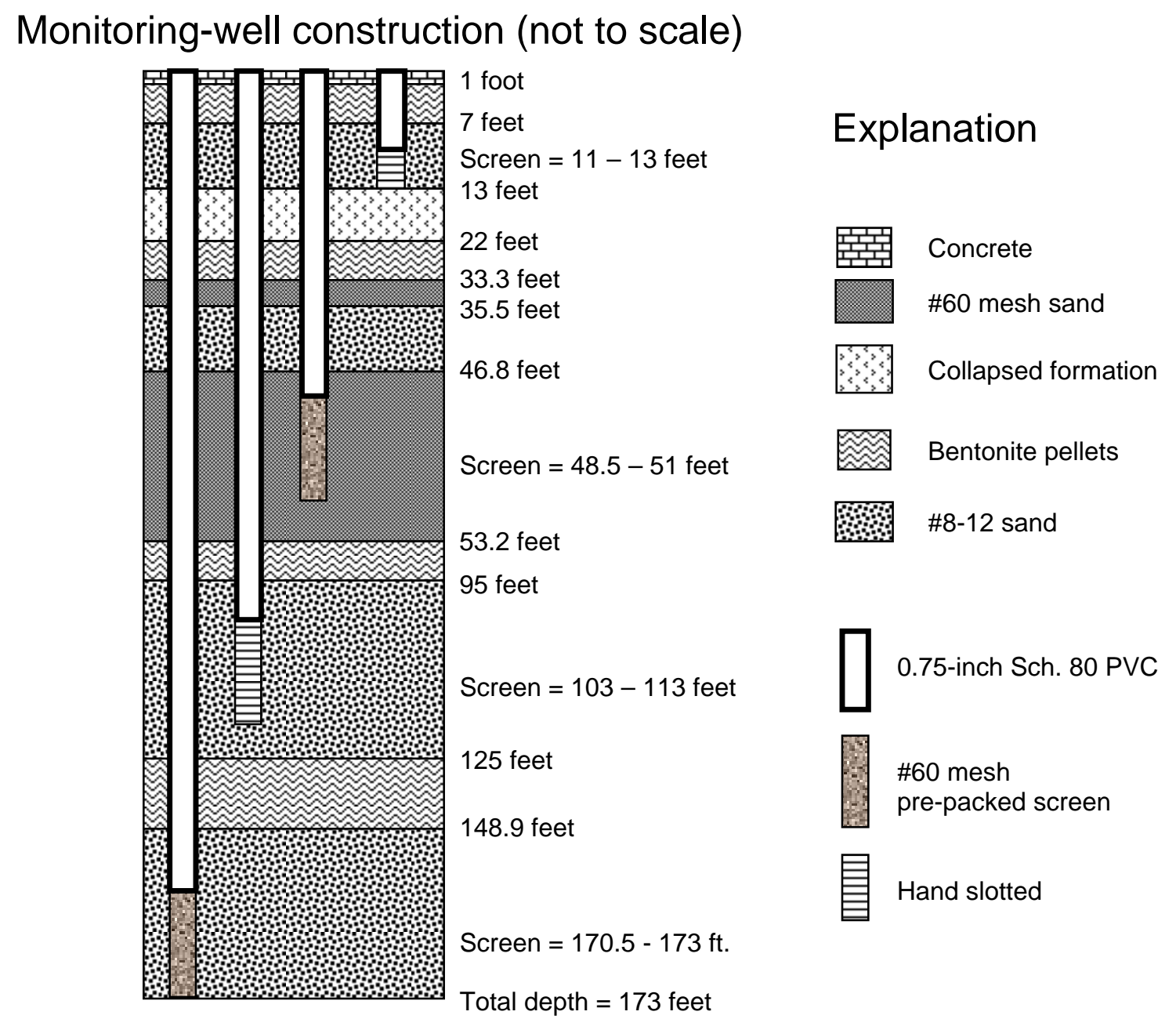

Figure 7. Completion diagram of MPG-D. 


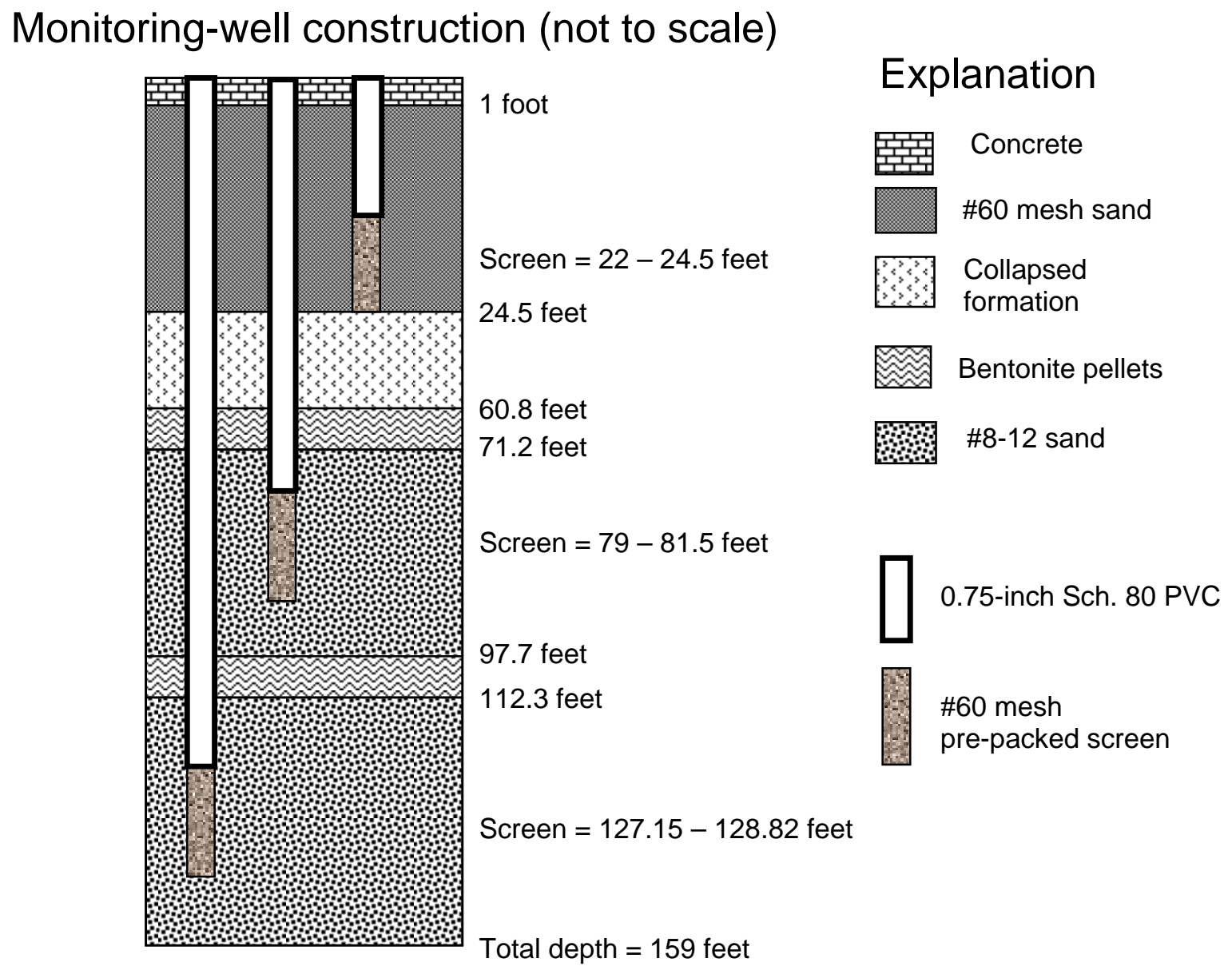

Figure 8. Completion diagram of LPG-D. 


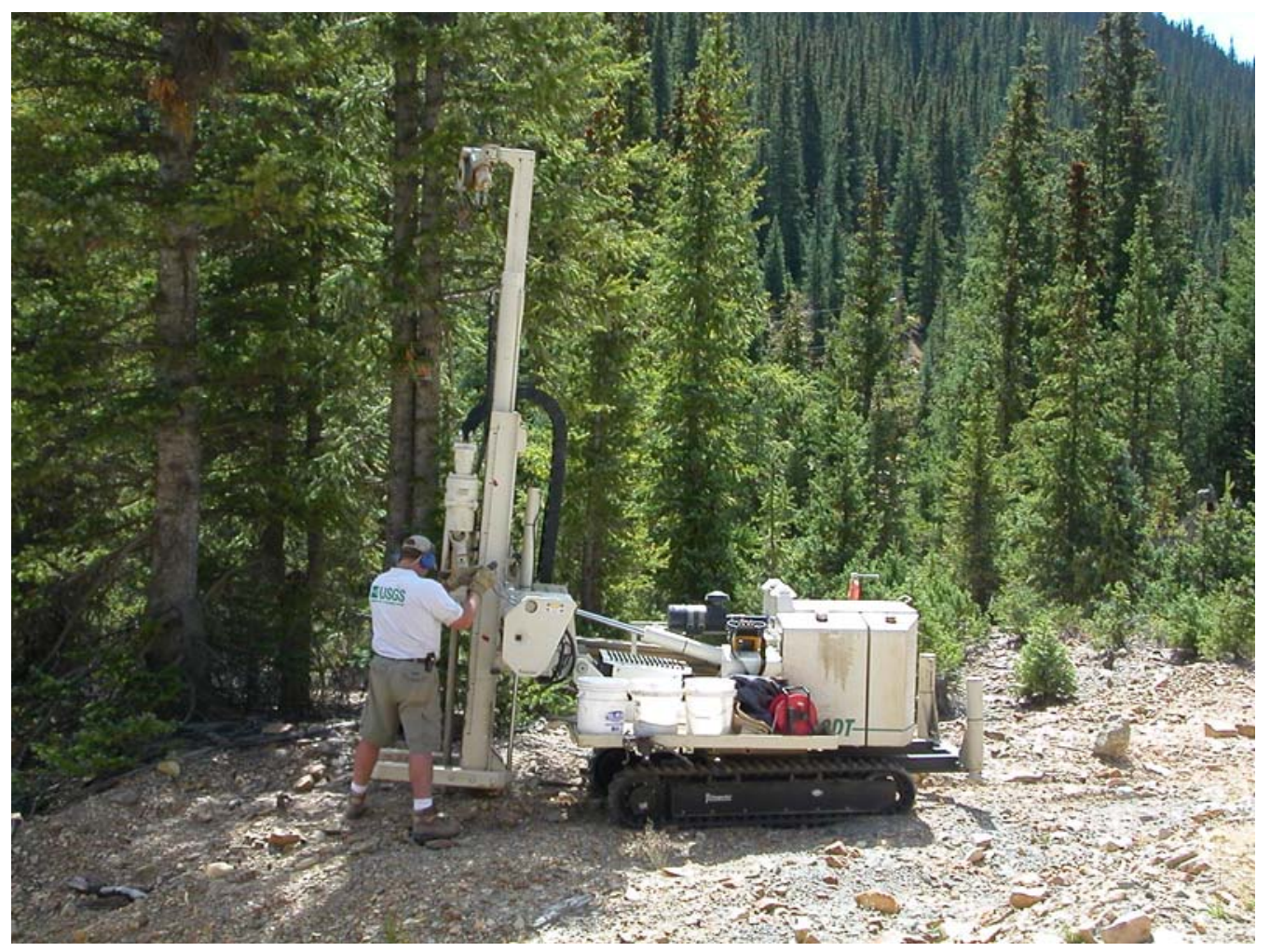

Figure 9. Geoprobe model 5410D rig near the mouth of Prospect Gulch (GPPG10) operated by the U.S. Geological Survey under Bureau of Land Management contract. 
Upper Prospect Gulch Generalized Well-Core Log

Depth, in feet

0 5

10

15

20

25

30

35

40

45

50

55

60

65

70

75

80

85

90

95

100

105

110

115

120

125

130

135

140

145

150

155

150

160

Continued on next page
Split spoon interval 17 - 17' 9"-- Quartz-pyrophyllite(?) altered clasts in an iron-rich matrix containing possible schwertmannite (?).
Gray dacite porphyry with white, former potassium feldspars to $2 \mathrm{~cm}$ across replaced by sericite between 22 to $24 \mathrm{ft}$.

Primary rock type is not discernible below 24 feet, which consists primarily of gray, silicified hydrothermal breccia. Breccia clasts are angular and range in size from a few millimeters to several centimeters across.

Intensely fractured interval at 31 to $32 \mathrm{ft}$, fractures are generally oxidized and coated with goethite and jarosite. Veins at $34 \mathrm{ft}$ have $0.5-\mathrm{cm}$ bleached halos; iron oxides coat vein surfaces.

Intensely fractured interval between 38 to $43 \mathrm{ft}$, one fracture at $42 \mathrm{ft}$ coated with $1-\mathrm{cm}$-wide yellowish precipitate (jarosite ?) fractures are generally oxidized and coated with goethite and jarosite. Finely disseminated sub-1-mm pyrite.

Intensely fractured interval between 49 to $51 \mathrm{ft}$, one fracture at $53 \mathrm{ft}$. coated with $1-\mathrm{cm}$-wide yellowish precipitate (jarosite?).

Intensely fractured interval at 64 to $68 \mathrm{ft}$, fractures are generally oxidized and coated with white sericite followed by jarosite(?). Pyrite composes 15- 25 percent of core.

Relatively massive silicified interval with stockwork veining between 70 and $72 \mathrm{ft}$. Quartz pyrite vugs with sub-1-mm pyrite.

$D, D, D 000000$

Gray, silicified hydrothermal breccia.

Jarosite(?) coats a fracture at $\sim 85 \mathrm{ft}$. Pyrite composes 15 percent

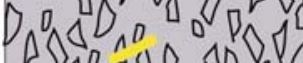
of core.

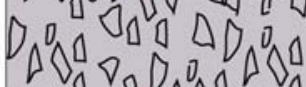
Da o o 0 a 8

Jarosite(?) coats a fracture at $\sim 96,97$, and $101 \mathrm{ft}$. Pyrite composes 5 percent of core. Kaolinite (Dickite?) along fracture at $98.5 \mathrm{ft}$. Kaolinite present along fractures and vugs to $138 \mathrm{ft}$

Gray dacite porphyry, slightly brecciated with white, former potassium feldspars to $2 \mathrm{~cm}$ across replaced by sericite between 99.5 to $109 \mathrm{ft}$.

Gray, silicified hydrothermal breccia.

Jarosite(?) on fractures at several depths between 116 and $130 \mathrm{ft}$. A white mineral (sericite ?) is present on some fractures, which pre-dates jarosite precipitation. Pyrite composes $~ 10$ percent of core. Pyrite-lined vugs occur throughout the interval 123 to $166 \mathrm{ft}$ to $2 \mathrm{~cm}$ wide.

Pyrite composes $\sim 5$ percent of core.

Figure 10. Generalized core log for UPG-D.

Core logged by Doug Yager and Ray Johnson, Aug. 19, 2004 
Upper Prospect Gulch Generalized Well-Core Log

Depth, in feet

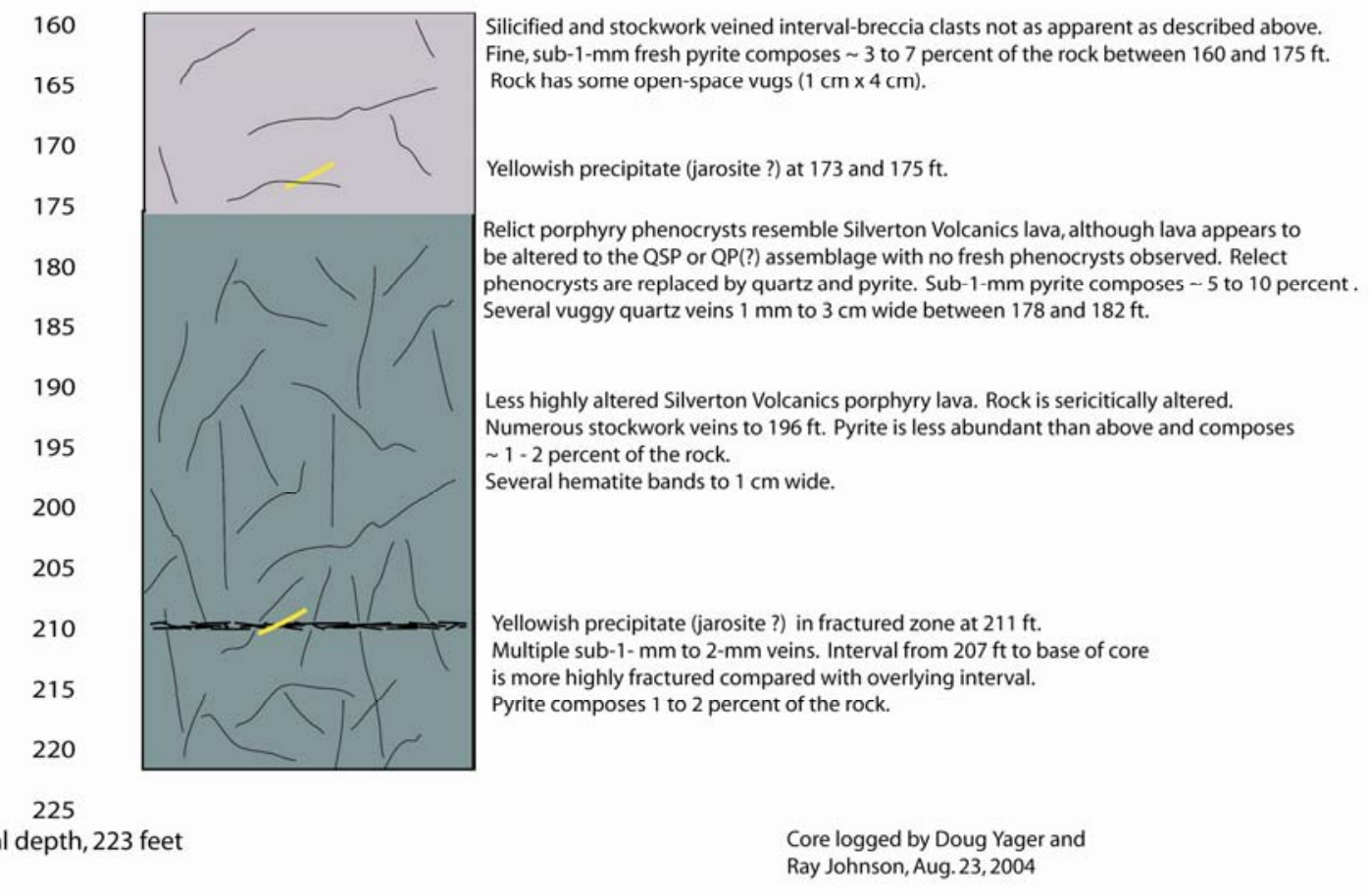

Figure 10. Generalized core log for UPG-D—Continued. 


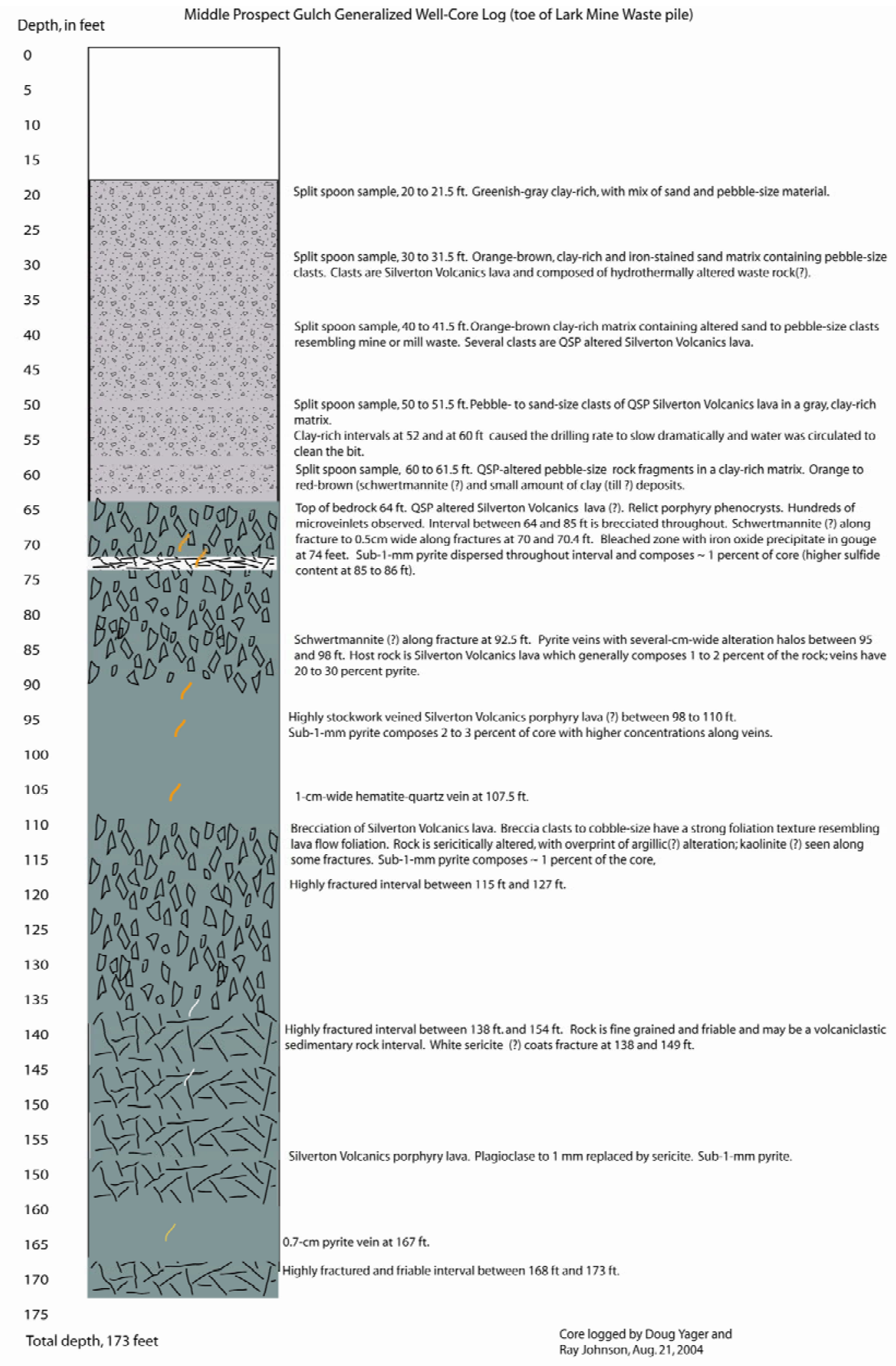

Figure 11. Generalized core log for MPG-D. 
Depth, in feet

10

15

20

25

30

35

40

45

50

55

60

65

70

75

80

85

90

95

100

105

110

115

120

125

130

135

140

145

150

155

150

160

Total depth, 159 feet
Subrounded volcanic clasts in an iron-rich sandy-soil matrix. QSP-altered clasts at base of

5 - $\mathrm{ft}$ split spoon sample. Alluvial ferricrete encountered at $\sim 8 \mathrm{ft}$.

Alluvial ferricrete with rounded to subrounded, cobble- and pebble-size clasts cemented by filamentous to boxwork-textured iron-oxide ferricrete matrix. Clasts are mainly Silverton Volcanics porphyry lava with occasional highly silicified clasts and some lava clasts have leisegangue bands. Crude bedding observed at $\sim 11$ to $13 \mathrm{ft}$ and $17 \mathrm{ft}$ to $18 \mathrm{ft}$; reverse grading is preserved in the interval between $18.5 \mathrm{ft}$ and $23.5 \mathrm{ft}$.

Cobble- to boulder-size clasts encountered at $\sim 25 \mathrm{ft}$ that coincided with some loss of drilling fluid circulation. No definitive indications of ferricrete below $25 \mathrm{ft}$, although some clasts and fractures are coated with iron oxide precipitates. Clasts are heterogeneous and consist of a variety of lithologies that represent several alteration assemblages. Clasts of dacite porphyry, propylitically altered Silverton Volcanics lava, and clasts altered to the quartz-alunite assemblage compose the interval.

Angular to subrounded, pebble- to cobble-size clasts of mainly Silverton Volcanics lavas are enclosed in a moderately well indurated brownish-gray clay-rich matrix. May be of glacial origin (till or debris flow?). Sparse, disseminated, sub-1-mm pyrite observed throughout the matrix. Pebble-to cobble-size clasts are primarily subrounded at $\sim 48.5 \mathrm{ft}$ Brownish-gray clay-rich, pebble and cobble interval continues, with several breaks where larger clasts were encountered while drilling, to $\sim 73 \mathrm{ft}$.

Brownish-gray clay-cemented pebble-to cobble-size clasts are primarily subrounded at $\sim 48.5 \mathrm{ft}$. Brownish-gray clay-rich, pebble and cobble interval continues with disseminated sub-1-mm pyrite, interrupted only by several breaks where larger clasts were encountered while drilling, to $\sim 73 \mathrm{ft}$.

Angular to subrounded pebbles in poorly indurated, subrounded sandy matrix; disseminated sub-1-mm pyrite in sand matrix. Between $68 \mathrm{ft}$ and $73 \mathrm{ft}$ there was only 20 percent recovery of core,and between $\sim 68.5 \mathrm{ft}$ and $\sim 73.5 \mathrm{ft}$ only 2 percent recovery of core.

Poor core recovery at $\sim 73 \mathrm{ft}$ may be due to intersection of the highly fractured top of Silverton Volcanics bedrock: however, obvious bedrock core did not commence until $\sim 80 \mathrm{ft}$.

Weak sericite-pyrite altered Silverton Volcanics porphyry lava (Burns Member), highly fractured top of bedrock at $\sim 80 \mathrm{ft}$. Rock is purple-greenish-gray and composed of 2 -mm phenocrysts replaced by chlorite and epidote, $\sim 5$ percent sub-1-mm pyrite coats fracture surfaces; sparse pyrite throughout groundmass. Rock is highly fractured; iron stains fracture surfaces. 1-cm-wide quartz veins with cockscomb texture common to $89 \mathrm{ft}$.

Iron -oxide and jarosite(?) coat a fracture at $\sim 89 \mathrm{ft}$; iron oxide and sericite(?) fill a fracture at $\sim 91 \mathrm{ft}$. Horsetail veins composed of quartz-pyrite and vuggy 1-mm quartz-pyrite veins occur in the interval $92 \mathrm{ft}$ to $94 \mathrm{ft}$. Interval is highly fractured between 90 and $100 \mathrm{ft}$.

Highly fractured interval encountered between $103 \mathrm{ft}$ and $110 \mathrm{ft}$; fractures stayed saturated with drilling fluid longe between $103 \mathrm{ft}$.and $105 \mathrm{ft}$, when compared to fractures for all overlying Silverton Volcanics bedrock. Fractures are frequently coated with various mineral precipitates. Pinkish-white sericite(?) coats a fracture surface at $103 \mathrm{ft}$, while jarosite and iron-oxide coat a fracture at $\sim 105 \mathrm{ft}$. Less altered propylitic assemblage of the Silverton Volcanics (Burns Member) was encountered at $\sim 107 \mathrm{ft}$ containing 2-mm plagioclase aligned along flow layering. Sub-1-mm pyrite composes $\sim<1$ percent of the rock. In general, highly fractured Silverton Volcanics (Burns Member) continues to $127 \mathrm{ft}$ where a change in alteration occurs.

Highly fractured interval between $115 \mathrm{ft}$ and $127 \mathrm{ft}$.

Slickenside surface filled with quartz observed at $\sim 122 \mathrm{ft}$.

Large, $0.5-\mathrm{cm}$ to $2-\mathrm{cm}$ irregular subrounded to angular clasts of Silverton Volcanics replaced by chlorite in a hydrothermal, quartz-rich matrix. Clasts likely formed due to hydrothermal brecciation. Alternatively, a thin zone of volcaniclastics may be partially altered and silicified. Foliation of clasts observed at $\sim 133 \mathrm{ft}$. The interval between $\sim 128 \mathrm{ft}$ to $135 \mathrm{ft}$ is a less fractured, competent interval when compared with the overlying core.

Interval between $\sim 136.5 \mathrm{ft}$ and $143 \mathrm{ft}$ is characterised by sub-mm- to $1 \mathrm{~cm}$-wide vuggy quartz veins, with disseminated, sub-1-mm sulfides and fluorite. Interval is hydrothermally altered with several vuggy zones observed to $148 \mathrm{ft}$.

Slickenside surface filled with quartz observed at $\sim 151 \mathrm{ft}$.

Highly fractured interval between $144 \mathrm{ft}$ and $147 \mathrm{ft}$

Less altered, propylitically altered Burns Member of the Silverton Volcanics lava encountered at $\sim 151 \mathrm{ft}$. Rock is purple-greenish-gray and composed of 1-mm phenocrysts replaced by chlorite. Sub-1-mm pyrite disseminated throughout the groundmass composes $\sim 3$ percent of the rock. Slickenside surface filled with quartz observed at $\sim 151 \mathrm{ft}$ Relatively competent interval observed to bottom of hole

\section{Figure 12. Generalized core log for LPG-D.}


Table 1. Completion data for wells and piezometers. [m, meters; ft, feet; “, inch]

\begin{tabular}{|c|c|c|c|c|c|c|}
\hline Location & $\begin{array}{l}\text { Latitude } \\
\text { (decimal } \\
\text { degrees) }\end{array}$ & $\begin{array}{l}\text { Longitude } \\
\text { (decimal } \\
\text { degrees) }\end{array}$ & $\begin{array}{l}\text { Elevation } \\
\text { (m) }\end{array}$ & $\begin{array}{c}\text { Elevation } \\
\text { (ft) }\end{array}$ & Type & Description \\
\hline UPG-D-40 & 37.8952827 & -107.6848674 & $3,607.95$ & $11,837.10$ & well & upper elevation well \\
\hline UPG-D-70 & 37.8952827 & -107.6848674 & $3,607.95$ & $11,837.10$ & well & upper elevation well \\
\hline UPG-D-105 & 37.8952827 & -107.6848674 & $3,607.95$ & $11,837.10$ & well & upper elevation well \\
\hline UPD-D-220 & 37.8952827 & -107.6848674 & $3,607.95$ & $11,837.10$ & well & upper elevation well \\
\hline MPG-S-12 & 37.8915823 & -107.6838561 & $3,451.13$ & $11,322.61$ & piezometer & middle elevation shallow piezometer \\
\hline MPG-S-20 & 37.8915823 & -107.6838561 & $3,451.13$ & $11,322.61$ & piezometer & middle elevation shallow piezometer \\
\hline MPG-D-13 & 37.8922303 & -107.6811235 & $3,434.02$ & $11,266.48$ & well & middle elevation deep well \\
\hline MPG-D-51 & 37.8922303 & -107.6811235 & $3,434.02$ & $11,266.48$ & well & middle elevation deep well \\
\hline MPG-D-112 & 37.8922303 & -107.6811235 & $3,434.02$ & $11,266.48$ & well & middle elevation deep well \\
\hline MPG-D-173 & 37.8922303 & -107.6811235 & $3,434.02$ & $11,266.48$ & well & middle elevation deep well \\
\hline LPG-D-25 & 37.8829656 & -107.6677624 & $3,146.23$ & $10,322.26$ & well & lower elevation well \\
\hline LPG-D-86 & 37.8829656 & -107.6677624 & $3,146.23$ & $10,322.26$ & well & lower elevation well \\
\hline LPG-D-159 & 37.8829656 & -107.6677624 & $3,146.23$ & $10,322.26$ & well & lower elevation well \\
\hline LGP-1 & 37.8926563 & -107.6814151 & $3,445.41$ & $11,303.83$ & piezometer & BLM geoprobe hole \\
\hline LGP-2 & 37.8925464 & -107.6810315 & $3,443.55$ & $11,297.74$ & piezometer & BLM geoprobe hole \\
\hline LGP-3 & 37.8929278 & -107.6817195 & $3,458.31$ & $11,346.16$ & piezometer & BLM geoprobe hole \\
\hline LGP-4 & 37.8930636 & -107.6809829 & $3,460.82$ & $11,354.41$ & piezometer & BLM geoprobe hole \\
\hline LGP-5 & 37.8932301 & -107.6815236 & $3,470.82$ & $11,387.20$ & piezometer & BLM geoprobe hole \\
\hline GPPG 1 & 37.8798037 & -107.6698466 & $3,126.97$ & $10,259.09$ & piezometer & Geoprobe point above upper bog \\
\hline GPPG 5 & 37.8809120 & -107.6685758 & $3,131.78$ & $10,274.85$ & piezometer & Geoprobe point along road \\
\hline GPPG 6 & 37.8812179 & -107.6685674 & $3,133.10$ & $10,279.22$ & piezometer & Geoprobe point along road \\
\hline GPPG 7 & 37.8814565 & -107.6682467 & $3,132.97$ & $10,278.77$ & piezometer & Geoprobe point along road \\
\hline GPPG 8 & 37.8819331 & -107.6677976 & $3,134.49$ & $10,283.75$ & piezometer & Geoprobe point along road \\
\hline GPPG 9 & 37.8822729 & -107.6678322 & $3,138.47$ & $10,296.81$ & piezometer & Geoprobe point along road \\
\hline GPPG 10 & 37.8823739 & -107.6673522 & $3,138.06$ & $10,295.46$ & piezometer & Geoprobe point along road \\
\hline GPPG 11 & 37.8827383 & -107.6673504 & $3,140.48$ & $10,303.43$ & piezometer & Geoprobe point along road \\
\hline GPPG 12 & 37.8832397 & -107.6668191 & $3,139.84$ & $10,301.31$ & piezometer & Geoprobe point along road \\
\hline GPPG 14 & 37.8837821 & -107.6666331 & $3,140.83$ & $10,304.55$ & piezometer & Geoprobe point along road \\
\hline GPPG 15 & 37.8840748 & -107.6664378 & $3,141.52$ & $10,306.83$ & piezometer & Geoprobe point along road \\
\hline GPPG 16 & 37.8844705 & -107.6659293 & $3,142.29$ & $10,309.37$ & piezometer & Geoprobe point near ski lift \\
\hline GPPG 17 & 37.8825523 & -107.6669662 & $3,136.49$ & $10,290.31$ & piezometer & Geoprobe point installed off of road \\
\hline
\end{tabular}


Table 1. Completion data for wells and piezometers-Continued.

\begin{tabular}{|c|c|c|c|c|c|c|c|}
\hline Location & $\begin{array}{l}\text { Install } \\
\text { date }\end{array}$ & $\begin{array}{l}\text { Sand } \\
\text { top (ft) }\end{array}$ & $\begin{array}{l}\text { Screen } \\
\text { top (ft) }\end{array}$ & $\begin{array}{c}\text { Screen } \\
\text { bottom (ft) }\end{array}$ & $\begin{array}{l}\text { Sand pack } \\
\text { bottom (ft) }\end{array}$ & $\begin{array}{l}\text { Total hole } \\
\text { depth (ft) }\end{array}$ & Screen type \\
\hline UPG-D-40 & $7 / 11 / 2005$ & 27 & 30 & 40 & 43 & 223 & hand-slotted pipe \\
\hline UPG-D-70 & $7 / 11 / 2005$ & 60 & 65 & 70 & 75 & 223 & hand-slotted pipe \\
\hline UPG-D-105 & $7 / 11 / 2005$ & 90 & 95 & 105 & 110 & 223 & hand-slotted pipe \\
\hline UPD-D-220 & $7 / 11 / 2005$ & 196 & 219.5 & 223 & 223 & 223 & BARCAD \\
\hline MPG-S-12 & $9 / 3 / 2004$ & 5 & 7 & 12 & 13 & 20 & hand-slotted pipe \\
\hline MPG-S-20 & $9 / 3 / 2004$ & 15 & 17 & 20 & 20 & 20 & hand-slotted pipe \\
\hline MPG-D-13 & $9 / 2 / 2004$ & 7 & 11 & 13 & 13 & 173 & hand-slotted pipe \\
\hline MPG-D-51 & $9 / 2 / 2004$ & 33.3 & 48.5 & 51 & 53.2 & 173 & BARCAD \\
\hline MPG-D-112 & 9/2/2004 & 95 & 103 & 113 & 125 & 173 & hand-slotted pipe \\
\hline MPG-D-173 & 9/2/2004 & 148.9 & 170.5 & 173 & 173 & 173 & BARCAD \\
\hline LPG-D-25 & $8 / 31 / 2004$ & 1 & 22 & 24.5 & 24.5 & 159 & BARCAD \\
\hline LPG-D-86 & $8 / 31 / 2004$ & 71.2 & 79 & 81.5 & 97.7 & 159 & BARCAD \\
\hline LPG-D-159 & 8/31/2004 & 112.3 & 127.15 & 128.82 & 159 & 159 & BARCAD \\
\hline LGP-1 & 2003 & 2 & 18.24 & 23.24 & 23.24 & 23.24 & 0.010" preslotted \\
\hline LGP-2 & 2003 & 2 & 32.95 & 37.95 & 37.95 & 37.95 & 0.010" preslotted \\
\hline LGP-3 & 2004 & 2 & 17.33 & 22.33 & 22.33 & 22.33 & 0.010" preslotted \\
\hline LGP-4 & 2003 & 2 & 14.62 & 19.62 & 19.62 & 19.62 & 0.010" preslotted \\
\hline LGP-5 & 2004 & 2 & 28.33 & 33.3 & 33.3 & 33.3 & 0.010" preslotted \\
\hline GPPG 1 & $9 / 16 / 2004$ & 2 & 3.25 & 5.75 & 5.75 & 5.75 & 0.010" preslotted \\
\hline GPPG 5 & $9 / 16 / 2004$ & 2 & 8.5 & 13.50 & 13.50 & 13.50 & 0.010" preslotted \\
\hline GPPG 6 & $9 / 16 / 2004$ & 2 & 4.75 & 7.25 & 7.25 & 7.25 & 0.010" preslotted \\
\hline GPPG 7 & 9/16/2004 & 2 & 10.3 & 15.30 & 15.30 & 15.30 & 0.010" preslotted \\
\hline GPPG 8 & 9/16/2004 & 2 & 6.6 & 11.60 & 11.60 & 11.60 & 0.010" preslotted \\
\hline GPPG 9 & $9 / 16 / 2004$ & 2 & 4.33 & 6.83 & 6.83 & 6.83 & 0.010" preslotted \\
\hline GPPG 10 & $9 / 16 / 2004$ & 2 & 3.8 & 8.80 & 8.80 & 8.80 & 0.010" preslotted \\
\hline GPPG 11 & 9/16/2004 & 2 & 3.5 & 8.50 & 8.50 & 8.50 & 0.010" preslotted \\
\hline GPPG 12 & $9 / 16 / 2004$ & 2 & 4.8 & 9.80 & 9.80 & 9.80 & 0.010" preslotted \\
\hline GPPG 14 & 9/16/2004 & 2 & 3.24 & 5.74 & 5.74 & 5.74 & 0.010" preslotted \\
\hline GPPG 15 & $9 / 16 / 2004$ & 2 & 10.95 & 15.95 & 15.95 & 15.95 & 0.010" preslotted \\
\hline GPPG 16 & $9 / 16 / 2004$ & 2 & 10.4 & 15.40 & 15.40 & 15.40 & 0.010" preslotted \\
\hline GPPG 17 & $9 / 15 / 2004$ & 2 & 3.5 & 6.00 & 6.00 & 6.00 & 0.010" preslotted \\
\hline
\end{tabular}


Table 2. Data for UPD-D well core on fracture density and orientation.

[ft, feet; in, inch]

\begin{tabular}{|c|c|c|c|c|}
\hline $\begin{array}{c}\text { Zone } \\
\text { (ft) }\end{array}$ & $\begin{array}{c}\text { Approximate } \\
\text { fracture } \\
\text { spacing (in) }\end{array}$ & $\begin{array}{c}\text { Major } \\
\text { Angle } \\
\text { (degrees) }\end{array}$ & $\begin{array}{c}\text { Minor } \\
\text { Angle } \\
\text { (degrees) }\end{array}$ & Comments \\
\hline $22-27$ & $2-3$ & 40 & & \\
\hline $27-31$ & $4-7$ & 40 & & \\
\hline $31-32$ & $1-2$ & $30-40$ & 0 & \\
\hline $32-35$ & $3-5$ & $30-40$ & 0 & \\
\hline $35-37$ & $6-8$ & 40 & $0-20$ & \\
\hline $37-44$ & $2-3$ & $\begin{array}{l}60-70 \\
30-40 \\
\end{array}$ & $\begin{array}{c}90 \\
0\end{array}$ & \\
\hline $44-47$ & $4-8$ & $30-50$ & & \\
\hline $47-53$ & $1-3$ & $\begin{array}{l}30-40 \\
60-70 \\
\end{array}$ & 0 & \\
\hline $53-64$ & $8-10$ & $\begin{array}{l}40 \\
70\end{array}$ & 0 & \\
\hline $64-68$ & $1-4$ & $60-70$ & $\begin{array}{c}0 \\
90 \\
\end{array}$ & \\
\hline $68-80$ & $4-9$ & $40-50$ & $\begin{array}{c}60-70 \\
0-10 \\
90 \\
\end{array}$ & \\
\hline $80-83$ & $2-3$ & 70 & $\begin{array}{c}40-50 \\
20\end{array}$ & \\
\hline $83-95$ & $6-12$ & $\begin{array}{c}30-50 \\
70\end{array}$ & & \\
\hline $95-98.5$ & $2-5$ & $\begin{array}{c}40-50 \\
70 \\
90\end{array}$ & & \\
\hline $98.5-138$ & $7-10$ & $\begin{array}{c}40-50 \\
70\end{array}$ & & \\
\hline $138-167$ & $7-20$ & $\begin{array}{l}60-80 \\
40-50 \\
\end{array}$ & & \\
\hline $167-169$ & $2-3$ & $\begin{array}{l}70 \\
90\end{array}$ & $\begin{array}{c}90 \\
0\end{array}$ & \\
\hline $169-210$ & $10-16$ & $\begin{array}{l}40-50 \\
70-80\end{array}$ & & \\
\hline $210-223.83$ & 7 & $\begin{array}{l}40-50 \\
70-80\end{array}$ & $\begin{array}{c}80-90 \\
0\end{array}$ & \\
\hline
\end{tabular}


Table 3. Data for MPD-D well core on fracture density and orientation. [ft, feet; in, inch]

\begin{tabular}{|c|c|c|c|c|}
\hline $\begin{array}{c}\text { Zone } \\
\text { (ft) }\end{array}$ & $\begin{array}{c}\text { Approximate } \\
\text { Fracture } \\
\text { Spacing (in) }\end{array}$ & $\begin{array}{c}\text { Major } \\
\text { Angle } \\
\text { (degrees) }\end{array}$ & $\begin{array}{c}\text { Minor } \\
\text { Angle } \\
\text { (degrees) }\end{array}$ & Comments \\
\hline $67-73$ & $5-10$ & $\begin{array}{c}40-50 \\
0-10\end{array}$ & & \\
\hline $73-75$ & & & & Very friable \\
\hline $75-98$ & 8 & $40-50$ & $\begin{array}{c}0-10 \\
70\end{array}$ & \\
\hline 98-105 & 5 & $40-50$ & $\begin{array}{c}70-80 \\
90\end{array}$ & \\
\hline $105-129$ & $10-15$ & $40-50$ & & \\
\hline $129-141$ & $7-10$ & $\begin{array}{l}50 \\
70\end{array}$ & 90 & \\
\hline $141-155$ & $\begin{array}{l}\text { Some } 5 \\
\text { Many } 1\end{array}$ & $\begin{array}{c}50 \\
70-80 \\
90\end{array}$ & & Very friable \\
\hline $155-167$ & $1-5$ & $\begin{array}{l}40-50 \\
70-80\end{array}$ & & \\
\hline $167-173$ & $\begin{array}{l}\text { Some } 5 \\
\text { Many } 1\end{array}$ & $40-50$ & & Very friable \\
\hline
\end{tabular}


Table 4. Data for LPD-D well core on fracture density and orientation. [ft, feet; in, inch]

\begin{tabular}{ccccc}
\hline $\begin{array}{c}\text { Zone } \\
\text { (ft) }\end{array}$ & $\begin{array}{c}\text { Approximate } \\
\text { Fracture } \\
\text { Spacing (in) }\end{array}$ & $\begin{array}{c}\text { Major } \\
\text { Angle } \\
\text { (degrees) }\end{array}$ & $\begin{array}{c}\text { Minor } \\
\text { Angle } \\
\text { (degrees) }\end{array}$ & Comments \\
\hline $78.58-88.58$ & 1 & & & Too fractured to measure angles \\
\hline $88.58-100$ & $1-2$ & $\begin{array}{c}60-70 \\
90\end{array}$ & & \\
\hline $100-102$ & $7-10$ & $\begin{array}{c}65 \\
0\end{array}$ & & \\
\hline $102-114$ & $2-4$ & $40-50$ & $\begin{array}{c}60-70 \\
0\end{array}$ & \\
\hline $114-127$ & $1-2$ & $40-50$ & $\begin{array}{c}60-70 \\
0\end{array}$ & \\
\hline $127-140$ & $7-15$ & $35-50$ & $\begin{array}{c}90 \\
70\end{array}$ & \\
\hline $140-148$ & 3 & $35-45$ & 70 & Lots of vertical quartz infilling \\
\hline $148-159$ & $7-15$ & $35-50$ & $60-80$ & \\
\hline
\end{tabular}


Table 5. Results from slug tests.

[m/s, meters per second; KGS, Kansas Geological Survey; K, hydraulic conductivity]

\begin{tabular}{|c|c|c|}
\hline Location & $\begin{array}{l}\text { Hydraulic conductivity } \\
(\mathrm{m} / \mathrm{s})\end{array}$ & Comments \\
\hline GPPG-5 & 1.9E-06 & Unconfined KGS, average of three tests. \\
\hline GPPG-8 & 1.0E-05 & Unconfined KGS, old stream channel. \\
\hline GPPG-12 & 7.9E-07 & Unconfined KGS, average of two tests, shallow point near wetlands. \\
\hline GPPG-14 & $1.2 \mathrm{E}-05$ & Unconfined KGS, average of two tests. \\
\hline GPPG-15 & 7.1E-06 & Unconfined KGS. \\
\hline GPPG-16 & 4.3E-06 & Unconfined KGS, second test better match. \\
\hline MPG-D-13 & 4.8E-06 & Unconfined KGS, average of two tests. \\
\hline LPG-D-25 & $6.4 \mathrm{E}-06$ & Confined KGS, average of three tests. \\
\hline LPG-D-86 & $4.8 \mathrm{E}-07$ & $\begin{array}{l}\text { Confined KGS, average of three tests, other methods not as good a fit and give } \\
\text { slightly lower values. }\end{array}$ \\
\hline LPG-D-159 & $7.8 \mathrm{E}-07$ & Confined KGS, average of three tests. \\
\hline LGP-3 & 3.4E-07 & $\begin{array}{l}\text { Unconfined KGS, appears to have a more permeable well skin, little effect on } \\
\text { formation K. }\end{array}$ \\
\hline LGP-5 & 7.9E-08 & $\begin{array}{l}\text { Unconfined KGS, appears to have a more permeable well skin, little effect on } \\
\text { formation K. }\end{array}$ \\
\hline Alluvial/colluvial & 5.E-06 & good representative number for modeling \\
\hline Fractured bedrock & 5.E-07 & good representative number for modeling \\
\hline Middle Prospect Gulch & 1.E-07 & good representative number for modeling \\
\hline
\end{tabular}

